\title{
Public Knowledge, Attitudes, Practices towards COVID-19 and assessment of risks of infection: An online cross-sectional survey in India
}

Arumuganainar Suresh ( $\nabla$ suresh.suresh@aastu.edu.et)

Addis Ababa Science and Technology University https://orcid.org/0000-0002-3193-0345

Rocktotpal Konwarh ( $\square$ rocketdbr@gmail.com )

Addis Ababa Science and Technology University https://orcid.org/0000-0003-4767-4531

Anand Pratap Singh

Uniglobe Scientific Pvt. Ltd

\section{Research Article}

Keywords: Attitude, COVID-19, India, Knowledge, Practice

Posted Date: January 18th, 2021

DOl: https://doi.org/10.21203/rs.3.rs-146461/v1

License: (c) (i) This work is licensed under a Creative Commons Attribution 4.0 International License.

Read Full License 


\title{
Public Knowledge, Attitudes, Practices towards COVID-19 and assessment of risks of infection: An online cross-sectional survey in India
}

\author{
Arumuganainar Suresh ${ }^{1,2, *}$, Rocktotpal Konwarh ${ }^{1,3, \$}$, Anand Pratap Singh ${ }^{3}$
}

${ }^{1}$ Department of Biotechnology, College of Biological and Chemical Engineering, Addis Ababa Science and Technology University, Addis Ababa-16417, Ethiopia.

${ }^{2}$ Department of Biological Sciences and Biotechnology, Institute of Advanced Research- The University for Innovation, Gandhinagar-382426, Gujarat, India.

${ }^{3}$ Uniglobe Scientific Pvt. Ltd. 7/9, Kishan Garh, Vasant Kunj, New Delhi-110070, India

Corresponding author: * suresh.suresh@aastu.edu.et (AS)

\section{\$rocketdbr@gmail.com (RK)}

\section{Authors Contribution}

Concept: Arumuganainar Suresh, Rocktotpal Konwarh

Methodology: Arumuganainar Suresh, Rocktotpal Konwarh, Anand Pratap Singh

Data analysis: Arumuganainar Suresh, Rocktotpal Konwarh, Anand Pratap Singh

Project administration: Arumuganainar Suresh, Rocktotpal Konwarh

Supervision: Arumuganainar Suresh, Rocktotpal Konwarh

Writing - original draft: Arumuganainar Suresh, Rocktotpal Konwarh

Writing - review \& editing: Arumuganainar Suresh, Rocktotpal Konwarh, Anand Pratap Singh 


\section{Abstract}

The global debacle, ushered in by the coronavirus disease 2019 (COVID-19) needs no elaboration. India has documented 10.5 million cases, of which 10.1 million have recovered while more than 151 thousand people have succumbed to the pandemic as of January 10, 2021. Of late, the second wave of the infection and new variants of the virus have also surfaced across various latitudes and longitudes of the globe. Various control measures have been adopted globally, however, the success and effectiveness of the control measures are affected by people's knowledge, attitudes, and practices (KAP) towards the pandemic. Therefore, the aim of this study was to determine the level of KAP toward COVID-19 among the Indian public. A cross-sectional online survey of Indian public was conducted between $18^{\text {th }}$ May 2020 and $24^{\text {th }}$ June 2020 . The survey questionnaire consisted of demographic characteristics, pertaining to knowledge (15 items), attitude (10 items), and practices ( 7 items), modified from a previously published questionnaire on COVID-19. A total of 566 persons completed the survey. The overall correct rate and the average score of the knowledge questionnaire were $75.8 \%$ and $13.6 \pm 2.7$ respectively. Attitude and practice scores were respectively $3.55 \pm 0.45 / 5$ and $2.75 \pm 0.43 / 3$ towards COVID19, respectively. Maximum respondents demonstrated moderate level of knowledge $(67.6 \%)$ and attitude (96\%) while $81.9 \%$ were found to follow good practices towards the pandemic. A positive correlation was observed between knowledge towards practice and attitude towards practices. Despite the good practice skills, a considerable percentage $(6 \%)$ of respondents never wore nose masks, washed hands, and maintained social distance during the outbreak. By the same token, 3.2 $\%$, and $14.9 \%$ of the public were in high and in the medium risk of infection, respectively. Due to the limited sample, we must be cautious when generalizing these findings to whole populations. 
Nevertheless, the study highlighted the indispensability of befitting health education programs aimed at improving KAP among the mass.

Keywords: Attitude; COVID-19; India; Knowledge; Practice

\section{Introduction}

With $\sim 90$ million cases and nearly 1.9 million mortality as on January 10, 2021, Coronavirus Disease 2019 (COVID-19) has spelled a global fiasco of unprecedented nature since December 2019. It includes $\sim 10.5$ million cases and $151 \mathrm{~K}$ deaths against 10 million recoveries from India alone since the first case of COVID-19, reported on January 30, 2020, in the state of Kerala, South India (Andrews et al., 2020). The number started escalating in late March 2020 and has been steadily increasing to date, however, the peak (97,894 cases/day) was reached in midSeptember $\left(16^{\text {th }}\right.$ September 2020$)$ while 16,311 new cases were documented on 10th January 2021. Global health experts and South Asian governments had expressed concern about the spread of COVID- 19 and the plausibility of more than 7.6 million deaths in South Asia alone in case of inaction (Walker et al, 2020). Thus, it becomes imperative that the people of India must be completely aware of the strategies to address the spread of COVID-19 and must adopt necessary measures.

Specifically, in the Indian context, the Prime Minister enforced a nation-wide lockdown on 25th March 2020 for 3-weeks initially while subsequent phases of lockdown were extended till May-end. Besides ensuring timely execution of the viral detection tests and endeavoring to develop effective vaccines, India has been beavering away to combat the debacle through various suggestive measures to reduce community spread and the overburdening of the country's health 
system. During the lockdown, Indians were only permitted to leave the house for basic activities such as buying groceries and seeking medical treatment. The lockdown also restricted Indians from leaving the country and all foreigners from entry. Non-essential sectors were ordered to close or allow employees to work from home. In India, circa $80 \%$ of the workers are employed in the informal sector, and about a third are employed as day-laborers. In this milieu, triggered rapid migration from the cities to rural areas in some parts of the country raised fears of the rapid spread of infections and exacerbation of existing health and economic inequalities (LGH, 2020).

Most European nations and Italy had reported a resurgence in the coronavirus infections, leading to a second wave of the deadly virus during the month of July, August, and September attributed to premature relaxation of strict interventions (Bontempi, 2020). Importantly, the infections during the second-wave have been considered to be far worse than the first due to the new variant SARS-CoV-2 (CNBC, 2020; Pedro et al, 2020. Xu and Li 2020). This had obviously posed further challenges to the already distressed population and in ensuring strict compliance with practice guidelines, such as social distancing, washing hands, and wearing masks. Albeit, various interventions to control the spread of SARS-CoV-2 are in place, howbeit, the path to return to normalcy seems to be an arduous one for various countries; thus, knowledge of the effect of each intervention is urgently required. Much seems to be highly cryptic as far as this novel virus is concerned; this further projects the indispensability of the strict compliance to the various precautionary guidelines to curb the spread of the virus. Most importantly, the global hunt for prompt and easy diagnostic measures (Konwarh, 2020a), effective therapeutic agents (Konwarh, 2020b), and potent vaccine (Le et al., 2020) continues to date, while vaccine-hesitancy (Coustasse et al., 2021) is another serious predicament. Strong infection control practices are the key to minimize the spread of the virus in both health care settings and the 
community (Li et al., 2020). However, experts are of the view that adherence to practices such as physical distancing and access to water and soap for handwashing and proper materials for covering the nose and mouth are big challenges in developing settings like India (Dahab et al., 2020). Moreover, misinformation, confusion, and misunderstanding about the virus itself, how it spreads, and the necessary precautions as well as unsupported treatments or promotion of ineffective preventive behaviors seem to aggravate the quandary (Ioannidis, 2020; Shimizu et al., 2020).

During first lockdown announcement, Indians reacted in panic and confusion. Panicbuying was a common observation while uncontrolled crowding of the public transportation hubs in the major cities to travel back to respective hometowns/villages posed a serious risk of infection. While this immediate reaction to the lockdown was envisaged, these actions provided grounds to raise questions regarding the status of understanding and attitude toward COVID-19 among Indians. However, on a positive note, the timely lockdown was reported to reduce the spread by $>60 \%$ in the month of May 2020 (Rampal, 2020). By April 2020, the Indian government had identified several hotspots of COVID-19 infections in the country. With the objective of successful 'flattening of the curve' in India, widespread and effective mitigation endeavors were undertaken. The Indian Ministry of Health and Family Welfare (MOHFW) along with state-level health departments have been providing information on COVID-19 through various communication channels and through a mobile application, Aarogya-Setu. However, as a matter of concern, with the ushering of the $2^{\text {nd }}$ wave (Pedro et al., 2020), a highly infectious new variant of SARS-CoV2 has been identified in UK (BBC, 2020), leading to the suspension of all flights to and from the United Kingdom to curb the new variant (https://www.pib.gov.in/PressReleasePage.aspx?PRID=1682426). However, the 
public's adherence to such control measures is affected by their KAP towards epidemic diseases (Ajilore et al., 2017). Therefore, this online survey was executed to investigate Indians' KAP and risk assessment towards the COVID-19 outbreak. We hope that the outcome of the survey will identify key variables to make informed decisions in the further control of COVID-19 by the relevant authorities.

\section{Materials and Methods}

\section{Survey Plan and Participants}

A quantitative survey-based approach was utilized keeping in view the appropriateness of a survey in assessing large populations with relative ease (Jones et al., 2013). This cross-sectional survey was conducted between May 18, 2020 and June 24, 2020 among Indians. During this period, the documented COVID-19 cases rose from 100,328 to 472,685 while 14,907 were dead. Citizens were informed to maintain social distance, wear mask, wash hands, and stop large gatherings while educational institutions were shut down, besides lockdown was imposed in various hotspots. It was not feasible to conduct an off-line survey during the outbreak, therefore we decided to collect online data using Google form. A one-page poster was prepared (Supplementary figure ES1). It was posted on various social media platforms such as WhatsApp, Facebook, Twitter, and Telegram and the data-documentation was solely based on the authors' networking. The poster contained an introduction, objectives, information about the requirements from the participants and the voluntary nature of their participation, declaration of anonymity and confidentiality, link and QR code, and the invigilators' details. Data were recorded from Indian citizens of age 15 years or more, who understood the content of the poster and agreed to voluntary participation in the study. 


\section{Ethical considerations}

All procedures performed in this study were designed and conducted in accordance with the ethical principles as laid under the "Committee on Publication Ethics (COPE)" guidelines. Confidentiality of the participants' information was ensured throughout the study. The online pages for the self-administered questionnaire could be accessed by the participants for attempting and completion, subjected to indication (through a click on 'Yes' button) of consent for voluntary participation.

\section{Questionnaires and score}

A survey questionnaire was designed, based on recent studies on COVID-19 in other countries. The questionnaire consisted of four parts: demographics of participants, knowledge, attitudes, and practices of COVID-19. Demographic variables included gender, age, marital status, education status, occupation, and state of residents. A total of 18 knowledge questionnaire of COVID-19 was developed by the authors (Table 2, Supplementary Table ES1). These questions were answered on multiple choices format and true/false basis with an additional 'I don't know' option. A correct answer was awarded 1 point and an incorrect or unanswered response fetched 0 points. The total knowledge score ranged from 0 to 18 while a cut off level of $<9$ was set for 'poor' and 10-15 for 'moderate', and >16 as 'good' knowledge. A total of 14 questions, pertaining to the assessment of the participants' attitudes towards COVID-19 (Table 3) was prepared and rated on the 5- point Likert scale ranging from strongly disagree (1), disagree (2), neutral (3), agree (4), and strongly agree (5) for positive attitude questions. As far as the negative-attitude questions were concerned, a score of 1 was awarded for the response- strongly agree, with the score increasing to 5 against the response- strongly disagree. People who scored $<35$ were classified as having a 'poor' 
attitude, those who scored 36-60 were classified as having a 'moderate' attitude and those who scored $>61$ were classified as having a 'good' attitude. A total of 8 practice questionnaires (Table 4) were prepared and rated on the 3-point Likert scale format ranging from never (1), sometimes (2), and always (3). In case of negative practice questions, the scores were reversed, e.g., 'always' was assigned a score of 1 and likewise. Scores of $<12$ indicated a 'poor' level of practices, scores of 13-20 indicated a 'moderate', and scores of $>21$ indicated a 'good' level of practices while responding to the outbreak of COVID-19. The assessment of the risk of infection was analyzed based on the practice skills.

\section{Statistical analysis}

The data collected from the survey were collated, followed by deletion of incomplete and duplicate responses. The first completed responses were counted as accurate. The descriptive statistics and one-way analysis of variance (ANOVA) or Chi-square test, as appropriate, were performed using Microsoft Excel to determine the differences between groups for selected demographic variables and their KAP toward COVID-19. Regression tests were applied to find any correlation between knowledge, attitude, and practice scores. The statistical significance level was set at $\mathrm{p}<0.05$.

\section{Results}

\section{Demographic characteristics}

A total of 625 participants attempted the survey questionnaire. Amongst these, 23 and 36 responses were incomplete and repetition of the attempts respectively. The first complete attempt was counted as a valid response and the repeated attempts and incomplete responses were excluded 
(59). The final data-sample consisted of 566 participants and the correct response rate was $90.6 \%$. Among these final respondents, almost equal representation of either gender was documented while the majority of the respondents were within the age group of 15-29 years (72\%), and unmarried (74.6\%) (Table 1). The majority of the respondents either held or pursued college-level education $(95.2 \%)$ against 27 participants with school education $\left(<12^{\text {th }}\right.$ grade). In terms of occupation, more than half of the respondents $(55.7 \%)$ were students, followed by people in private jobs $(26.7 \%)$, government jobs $(8 \%)$, and the healthcare sector $(3 \%)$. The participants belonged to 25 states of the country out of 36 states and union territories with maximum representation from Assam (230), followed by Tamil Nadu (228), and rest from other 23 states. Pertinently, in seven states, only one participant answered (Figure 1). The various other demographic characteristics are shown in Table 1.

\section{Assessment of knowledge}

A total of 18 questions were used to gauge knowledge-status of the participants on COVID19. The average knowledge score for the participants was $13.6 \pm 2.7$, (range: $2-18$ ). The overall correct answer rate of the knowledge questionnaire was $75.8 \%(13.6 / 18 * 100)$ while the correct answer rates for all the participants ranged from $11 \%$ to $100 \%$. As shown in Table 2, with regards to knowledge and awareness about COVID-19, seven out of ten respondents chose the correct expansion of 'COVID-19' as Coronavirus disease 2019 (68.4\%) while the percent of correct responses pertaining to various other queries are presented within brackets: the origin of the disease $(95.6 \%)$, spreading modes $(91.5 \%)$, nature of the virus $(61 \%)$, main symptoms $(88.9 \%)$ and the-then current status of vaccine development (91.3\%). Around six out of ten respondents remarked the social distancing norms $(62.2 \%)$ and the possibility of pet animals, spreading the disease $(65.5 \%)$ as ' 6 feet' and 'False', respectively. Almost all participants $(98.8 \%)$ correctly 
chose 14 days as the quarantine period (14 days) for suspected people. Remarkably, three out of four participants correctly opted for RNA as the genetic material of the SARS-nCoV2. Knowledge scores significantly differed across education level $(\mathrm{p}<0.001)$, the states $(\mathrm{p}<0.01)$, and different age category $(\mathrm{p}<0.05)$ of the participants. However, no significant difference was observed for gender, marital status, and occupation categories (Table 5). In the case of knowledge

level towards COVID-19, generally speaking, the majority of the participants (67.6\%) had moderate knowledge and one out of four had good knowledge towards different COVID-19 related items, inquired in the study (Table 6). Comparison of knowledge level among the participants revealed a significant difference for three variables: education status $(\mathrm{p}<0.01)$, age, and occupation of the respondents $(\mathrm{p}<0.05)$ during the study period. There was no significant difference in the knowledge level as far as the variables of gender, marital status, and state of the respondents were concerned.

\section{Assessment of attitudes}

Table 3 represents the responses obtained for attitude items of questionnaire towards COVID-19. About $90 \%(\mathrm{n}=509)$ individuals (strongly agreed, $70.3 \%$ and agreed, $19.6 \%$ ) were of the view that COVID-19 was a serious health concern in society. Eight out of ten participants agreed that the Indian government had endeavored in a commendable perspective as far as controlling the spread of COVID-19 was concerned besides being upbeat about the successful containment of the current pandemic by the government. Even so, $13.4 \%$ of participants were neutral against disagreeing respondents of around $4.8 \%$ whether the virus would be controlled. Almost $67 \%$ of participants agreed that people were panicky in India and half of the participants were apprehensive of contacting the COVID-19 infection. Most of the participants (77.7 \%) 
thought that traveling was the main reason to contact the COVID-19 infection while $54.8 \%$ agreed that their daily life was spoiled due to the current pandemic. Approximately $66.4 \%$ of participants believed and agreed that patients recovered from COVID-19 infection could be allowed in society, while $16.6 \%$ disagreed. Against a small number of unwilling respondents (3.7 \%), the majority of the participants agreed to undergo self-isolation in case they showed the symptoms of COVID-19 (93.1\%). Around $41.7 \%$ and $46 \%$ of participants agreed that the COVID-19 virus was synthetic and a bioweapon while $\sim 33 \%$ were neutral in their viewpoint and the rest disagreed. Seven out of ten respondents appreciated the action of the Indian government to initiate the act of clapping on $22^{\text {nd }}$ March, 2020 in support of the healthcare workers for their tireless service. Six out of ten seconded the call of the Indian government to show our unity against COVID-19 by lighting lamps on 5th April 2020. The documented attitude-response significantly $(\mathrm{p}<0.001)$ differed among participants for all questions except the question of A7:'I am thinking about COVID-19 all day'. Unexpectedly, attitude score showed a reverse trend with the education level, for example, the participants with school education recorded 3.61/5, while those with Ph.D. registered a score of 3.46/5 (Table 5). In the case of attitude level towards COVID-19, generally speaking, the majority of the participants (96\%) had a moderate attitude, while only $2 \%$ 'poor' and $2 \%$ 'good' attitude towards different items of the inquiry were documented. There was no significant difference in the attitude level of any demographic variables (Table 6). Regression tests revealed that there was no statistically significant correlation between knowledge and attitude (Table 7).

\section{Assessment of practices}

Table 4 represents the responses obtained for practice items of the questionnaire towards COVID-19. Around $6 \%(n=35)$ of participants reported that they were 'never' following good 
practices towards COVID-19 such as wearing a nose mask, maintaining social distance, washing hands, and avoiding crowded places during the pandemic. However, around nine out of ten participants affirmed with an 'always' response, following the afore-stated good practices. Around $11 \%$ and $9 \%$ of participants respectively said that they were willing to attend functions and shake hands with friends during the outbreak. Almost, eight out of ten people supported lockdown imposed in the country to control COVID-19 spread and $6 \%$ voiced against it. All responses to the practice questions were significant at $\mathrm{p}<0.001$. Practice score increased with increase in education level, for example, participants holding school education exhibited 2.69/3, while 2.79/5 was recorded for the doctoral level education (Table 5). In the case of occupation category, healthcare workers showed more practice skills score (2.88) than others such as students (2.72), people in government jobs (2.85) and private jobs (2.77), and unemployed individuals (2.70). The practice score was significantly associated with age group $(\mathrm{p}<0.05)$, and the state of the respondents $(\mathrm{p}<0.001)$ (Table 5). In the case of practice level towards COVID-19, generally speaking, eight out of ten had a 'good' practice level, while $15 \%$ showed 'moderate' and $3.2 \%$ registered 'poor' practice skills towards different items of the inquiry (Table 6). Comparison of practice skills of different characteristics revealed that age $(\mathrm{p}<0.01)$, and state of participants $(\mathrm{p}<0.001)$ had significant differences during the survey period. There was no significant difference ( $>0.05)$ in the practice skills with respect to gender, marital status, education status, and occupation category. Regression tests revealed a statistically significant positive linear correlation between knowledge and practices $(r=0.116, \mathrm{p}<0.01)$ and attitude and practice scores $(r=0.164$, $\mathrm{p}<0.001)$ (Table 7).

\section{Assessment of Risk of infection}


Assessment of risks of infection was analyzed among all the respondents based on the eight practice questions (Table 4). According to the risk-categories, among all respondents, $3.2 \%(n=18)$ did belong to high-risk category, $14.9 \%(n=84)$ were in the medium-risk category, and most of the participants $(81.9 \%, n=464)$ were in the low-risk category (Table 6$)$. High-risk category people were those who responded with a 'never' remark for wearing a mask, washing hands, maintaining social distance, avoiding crowded places and an 'always', preferring handshake while meeting friends in this disease outbreak. The medium-risk category people were those who said 'some time' for the above practices, while the classification of the low-risk category people was based on their response as 'always' for the above practices. Comparatively, greater high-risk people belonged to male ( $4.5 \%$ ) compared to female (3.9\%), low aged (4.9\% for 15-29 years) in contrast to people in the age group, 30-49 years (1.3\%), unmarried (4.7\%) than married (2.8\%), and low educated (7.4\% for school education category) than higher educated (2.6\% for Ph.D. degree) categories (Figure 2).

\section{DISCUSSION}

Prompted by the dearth of scientific information on COVID-19 and the cryptic biochemical and genetic nature of SARS-CoV-2, the WHO had pressed upon the dire need to improve knowledge among the general mass as well as promote and disseminate information about prevention and control measures in health care and community settings (WHO, 2020). On the part of the health authorities, planning of appropriate strategies to prepare and manage the public had been identified as a prerequisite. In this context, the study of KAP of the population is of utmost importance to guide these efforts. To the best of our knowledge, this is the $3^{\text {rd }}$ study in India regarding the general public's KAP and assessment of risk of infection towards COVID-19 among 
Indians. However, the previous two studies were focused on KAP among the mass in the specific states of Bihar and Uttar Pradesh (phone survey) and online survey of the whole nation (Acharya et al., 2020; Roy et al., 2020). These previous studies had employed very limited questionnaires, especially questions pertaining to practice and risk assessment- a pertinent point at this moment.

Our survey encompassed almost equal representation of both the genders and welleducated population (95\% holding UG degree or more); we found the average knowledge score of Indians as moderate. A previous study by Roy et al. (2020) also evinced moderate knowledge among Indians towards the current pandemic. Even so, correct rates of knowledge score ranged widely among demographic variables indicating that some participants had good knowledge (24.7 $\%)$ and others showed poor knowledge (7.6\%) about the disease. Based on the limited information available to date, the risk of pet animals spreading COVID-19 to people is considered to be low (CDC, 2020). Nevertheless, a considerable fraction of the response $(23.7 \%)$ was the other way round. The same was documented by Roy et al. (2020). On the other hand, the pertinence of social distancing has been emphasized time and again in the context of preventive measures in the current pandemic. However, $36.8 \%$ of the respondents did not choose the officially recommended distance of 6 feet. Due to the origin of this disease, 1 in 4 participants wrongly expanded COVID19 as 'China originated Virus disease-2019', while a similar study in Ethiopia, 50 \% responded wrongly (Benor et al., 2020), thereby attesting the need for the dissemination of correct and timely knowledge among the public across various geographical pockets. The knowledge score significantly differed across education status and the states of the residents, reflective of the current COVID-19 information landscape in the country. Although the government and health authorities have been unswervingly disseminating COVID-19 information through Aarogya-Setu App since 
the disease was first detected in India, the build-up in false and inaccurate information cannot be overlooked (Ioannidis, 2020; Shimizu et al., 2020).

Several surveys, conducted in other countries have indicated differences in levels of knowledge on COVID-19 and correct knowledge rate among the general population. To cite for instance, the correct rates of $84.7 \%$ in Sudan (Mousa et al., 2020) and $80 \%$ in Nigeria (Isah et al., 2020) were documented against $74 \%$ in Ethiopia (Aynalam et al., 2020; Benor et al., 2020). Studies, conducted in Thailand (Srichan et al., 2020), Bangladesh (Haque et al., 2020), Egypt (Abdelhafiz et al., 2020), China (Zhong et al., 2020), Saudi Arabia (Al-Hanawi et al., 2020), Nepal (Hussain et al., 2020), Iran, (Kakemam et al., 2020), Malaysia (Azlan et al., 2020), and Syria (Al Ahdab, 2020) stand in testimony to the afore-stated statement. The differences in questionnaires, pertaining to gauging of knowledge-status, do not permit the accurate comparison of knowledge levels across these studies. Interestingly, knowledge score significantly differed with respect to the gender of the participants in various countries in contrast to assessments reported in this study and those in Egypt (Abdelhafiz et al., 2020) and Ethiopia (Benor et al., 2020). However, we found that male participants were at high risk than the female counterparts, in accordance with previous studies regarding gender patterns of risk-taking behavior- men are more likely to engage in risk-taking behaviors (Pawlowski et al., 2008; Cobey et al., 2013). Pertinently, Benor et al (2020) reported that the females were at high risk than the males in Ethiopia, forwarding the justification that women and girls are highly vulnerable in many settings and are at increased risk during an epidemic or crisis, attributable to the fact that they are responsible not only for caring for the elderly and children but also they often constitute more than half of the healthcare workforce (Wenham et al, 2020). 
In general, Indians (96\%) showed moderate attitude towards the current pandemic, while 2 $\%$ showed 'poor' and the rest $2 \%$ exhibited 'good' attitude towards the COVID-19. For instance, nine out of ten participants agreed to isolate themselves in case they start to exhibit the symptoms while eight out of ten seconded the governmental efforts in controlling the disease and are upbeat about the success in combating the pandemic. The drastic measure, undertaken by the Indian government in enforcing lockdown for the country in different stages and the efforts and actions to accelerate the tastings (more than million test/day) (Hindustan Times, 2020), provide funds (>100 million USD) for vaccine development (Business Today, 2020) provide related information through a mobile app (Aarogya Setu), and evacuate stranded Indians (>1,00,000 persons) in other countries (The Hindu, 2020), etc. merit special mention. On a note of pertinence, the percentage of participants reporting uncertainty toward government efforts in fighting against COVID-19 was low $(6.2 \%)$. Seven out of ten strongly agreed that the pandemic had posed a serious public health threat; it might be due to its highly contagious nature, the world scenario and great volumes of 'overstressed' information bounced by the media. However, only 1 out of 4 strongly accepted to have felt panicky, possibly attributable to the low mortality, observed in India $(<1.5 \%)$. Nine out of ten responded that they would isolate themselves if they showed COVID-19 symptoms; the same was observed by Roy et al. (2020). Almost half of the participants were of the view that this virus was developed as a bioweapon; a similar attitude-trend was observed in Nigeria (Olapegba et al., 2020) against a quarter of the participants slanting this view in Egypt (Abdelhafiz et al., 2020). There are conflicting schools of thought, one vouching for its bioweapon backdrop and the other advocating its natural origin. Four out of ten Indians agreed that it is a manufactured/ synthetic entity; almost similar response (36\%) was noticed among Nigerians (Isah et al., 2020) while 1 out of 5 respondents in Ethiopia believed likewise (Benor et al., 2020). 
Equipped with good knowledge and attitude towards the pandemic or epidemic diseases does not necessarily warrant that the people would not contract the disease; a decisive role is played by the practices. In this study, almost nine out of ten participants 'always' adopted precautions such as wearing a nose mask, maintaining social distance, avoiding crowded places, and washing hands. This indicated a high level of willingness among the participants to make behavioral changes towards the key practices to protect from COVID-19. A satisfactory practice skill towards COVID-19 in Indian residents was documented; this may be probably corroborated to the fact that this study was conducted when COVID 19 had already become a global health problem and the first case (post returning from Wuhan, China) was confirmed on $27^{\text {th }}$ January 2020 in India (Andrews et al., 2020). There are many factors associated with good practices, such as proper guidance, knowledge, attitude, age, place of residence, education level, occupation, and moreover availability of protection materials and its cost. Overall, the practice skills of the Indians towards COVID-19 were good and significantly differed $(\mathrm{p}<0.001)$ with respect to the age category and the states of residence. The correlational analysis also supported the findings of the present study as knowledge and attitudes were positively correlated with the practice skills, significantly. Pertinently, a person's intention to a specific behavior is a function of their attitude towards that behavior (Fisher et al., 1995]. The practice skills differed in other countries as well, for instance, only $36 \%$ of respondents expressed their willingness to wear a nose mask in Egypt and Ethiopia (Abdelhafiz et al., 2020; Benor et al., 2020) against the marks of 80\%, 49.3\% and 65\% in Tanzania, Sudan, and Nigeria respectively (Byanaku et al., 2020; Mousa et al., 2020; Isah et al., 2020). In a study from China, it was reported that almost all used face masks while going out during the pandemic (Zhong et al., 2020]. Similar to Indians, the neighboring countries of Bangladesh and 
Nepal had documented around $8 \%$ and $10 \%$ of people, not wearing nose masks, while $87 \%$ and $95 \%$, respectively wanted to maintain social distance (Haque et al., 2020; Hussain et al., 2020).

Most importantly, a significant percentage of participants ( $6 \%)$ did not follow the above precautions and $\sim 7 \%$ responded with 'sometimes' only. This is a very serious problem in the country at the moment, suggestive of the need for strict regulations immediately. Indeed, it appears that in the Indian context, the use of face masks is not a norm in society. It is uncommon for the typical Indian to wear a face mask when ill. These dangerous practices were more related to the male participants, particularly those in the young age-group (15-29), low education status, and more specifically, the students. Previous studies also suggested that such risks-taking behaviors are more linkable to the younger age, males, and poorly educated public (Zhong et al., 2020 Pawlowski et al., 2008). In many countries lockdown was imposed for certain days including India and eight out of ten Indians supported it. However, Roy et al. (2020) found that the >80\% of participants needed mental healthcare during lockdown among Indians due to paranoia about acquiring COVID-19 infection, distress related social media and sleep difficulties.

In the assessment for the risk of infection, around $3.2 \%$ and $15 \%$ of people were placed under high risk and medium risk category, respectively. Around $7 \%$ low educated (<12 grade) and five percent of male, students, and unmarried category were assigned under high-risk category based on their practice skills. These findings clearly indicated the importance of further improving practice skills among the public via imparting health education, which is foreseeable to concomitantly result in improvements in their attitudes and knowledge towards COVID-19. A study in the neighboring country of Bangladesh had shown that around $33 \%$ and $44 \%$ of the mass were in the high and the medium risks of infection, respectively (Haque et al., 2020) while Benor et al. (2020) had predicted around $18 \%$ of the Ethiopian population to be under the high risk of 
infection category. Undoubtedly, COVID-19 has been a serious public health problem around the world. Researchers are working diligently to explore different vaccines, treatment options, design cost-effective public health campaigns, and education programs. This survey, in fact, explicates the need for more comprehensive education programs with a focus on the consistency of robust information-dissemination from the government and related authorities.

\section{Limitations of the survey}

This survey was conducted based on the respective online network of the authors and relied on the circulation of the survey link on different social media platforms (WhatsApp, Facebook, Twitter, and Telegram). There is a possibility of bias as underprivileged populations may not have been able to participate in the survey. Moreover, when compared to the current population in India, the survey-sample was over representative for participants below the age of 50, students, and those from the states of Assam and Tamil Nadu. Therefore, the findings may not be a true representation from the perspective of the entire nation. A more systematic, community-based, inclusive sampling method (preferably conducted in local/official languages of different states and union territories) is recommended to improve the representativeness and generalizability of the findings. Another limitation of the study is the possibility of the respondents, providing socially desirable responses because during the survey period an alarming number of cases were being reported in India and this might limit generalizations. As this study used self-reported data, it is possible that participants may have forwarded their response against the attitude and practice questions in the positive connotation based on what they perceive to be expected of them (van de Mortel 2008), thus, they may be subject to bias. Despite these limitations, our findings are expected to provide valuable 
information about the KAP of Indians for further necessary action in the management efforts during the COVID-19 outbreak.

\section{Conclusion}

India is facing a stiff challenge to control the spread of COVID 19 among its population during the relaxation of preventive measures against COVID-19. Findings of this study show that the Indians have moderate knowledge, attitude, and good practice skills towards COVID-19, which is important to limit the spread of the disease. However, the KAP score significantly differed among demographic variables of age, education, and the state with respect to the knowledge, while age and state of the residents seemed to exert a profound dictate on the practices. Although the government has taken major steps to limit the spread of the disease, more effort is needed particularly during the $2^{\text {nd }}$ wave. The demographic variables linked to high risk of infection (1829 age, less education, and student-category) must be addressed appropriately. A positive correlation was observed between knowledge towards practice and attitudes towards practice skills. The outcomes of the study are envisaged to be of some assistance to public health policymakers and health workers. On a concluding note, we anticipate that health education programs would be augmented soon, particularly aimed at improving KAP towards COVID-19 among the high-risk populations. We are upbeat that with concerted endeavors of the Government and the people of the Indian nation, COVID-19 shall be vanquished.

\section{Supporting information}

\section{Supplementary Table ES1. Knowledge and awareness of Indians towards COVID-19 $(\mathbf{n}=566)$}

\section{Supplementary Figure ES1. Poster used for this study}




\section{Acknowledgments}

The authors acknowledge their gratitude to all the participants involved in this study for their cooperation and support.

\section{Conflict of interest}

The authors declare no conflict of interest

\section{Source of funding}

This research did not receive any funding.

\section{Data availability statement}

The datasets generated during and/or analysed during the current study are available from the corresponding author on reasonable request.

\section{References}

1. Abdelhafiz, A.S., Mohammed, Z., Ibrahim, M.E., Ziady, H.H., Alorabi, M., Ayyad, M. and Sultan, E.A., 2020. Knowledge, perceptions, and attitude of egyptians towards the novel coronavirus disease (COVID-19). Journal of Community Health, pp.1-10. https://doi.org/10.1007/s10900-020-00827-7

2. Acharya, R., Gundi, M., Ngo, T., Pandey, N., Patel, S.K., Pinchoff, J., Rampal, S., Saggurti, N., Santhya, K.G., White, C. and Zavier, A.J., 2020. COVID-19-related knowledge, attitudes, and practices among adolescents and young people in Bihar and Uttar Pradesh, 
India: Study description. https://knowledgecommons.popcouncil.org/departments_sbsrpgy/966/

3. Ajilore K, Atakiti I, Onyenankey K. College students' knowledge, attitudes and adherence to public service announcements on Ebola in Nigeria Suggestions for improving future Ebola prevention education programmes. Health Education Journal. 2017; 76: 648-60. https://doi.org/10.1177\%2F0017896917710969

4. Al Ahdab, S., 2020. Knowledge, Attitudes and Practices (KAP) towards pandemic COVID-19 among Syrians. https://doi.org/10.21203/rs.3.rs-27859/v2

5. Al-Hanawi, M.K., Angawi, K., Alshareef, N., Qattan, A.M., Helmy, H.Z., Abudawood, Y., Alqurashi, M., Kattan, W.M., Kadasah, N.A., Chirwa, G.C. and Alsharqi, O., 2020. Knowledge, Attitude and Practice Toward COVID-19 Among the Public in the Kingdom of Saudi Arabia: A Cross-Sectional Study. Frontiers in Public Health, 8. https://dx.doi.org/10.3389\%2Ffpubh.2020.00217

6. Andrews, M. A., Areekal, B., Rajesh, K. R., Krishnan, J., Suryakala, R., Krishnan, B., Muraly, C. P., Santhosh, P. V. 2020. First confirmed case of COVID-19 infection in India: A case report. Indian $J$ Med Res 151:490-2. https://www.ijmr.org.in/text.asp?2020/151/5/490/285776

7. Andrews, M.A., Areekal, B., Rajesh, K.R., Krishnan, J., Suryakala, R., Krishnan, B., Muraly, C.P. and Santhosh, P.V., 2020. First confirmed case of COVID-19 infection in India: A case report. The Indian Journal of Medical Research, 151(5), p.490. https://dx.doi.org/10.4103\%2Fijmr.IJMR_2131_20 
8. Aynalem, Y.A., Akalu, T.Y., Gebresellassie, B., Sharew, N.T. and Shiferaw, W.S., 2020. Assessment of undergraduate student knowledge, practices, and attitude towards COVID19 in Debre Berhan University, Ethiopia. https://doi.org/10.21203/rs.3.rs-28556/v1

9. Azlan, A.A., Hamzah, M.R., Sern, T.J., Ayub, S.H., Mohamad, E. 2020. Public knowledge, attitudes and practices towards COVID-19: A cross-sectional study in Malaysia. PLoS ONE 15(5): e0233668. https://doi.org/10.1371/journal.pone.0233668

10. BBC, 2020. https://www.bbc.com/news/health-55308211

11. Benor, S., Abera, S., Mandefro, A., Konwarh, R. and Suresh, A., 2020. Assessment on knowledge, attitude, practices and risk of infection towards COVID-19 in Ethiopia: An online cross-sectional survey. https://doi.org/10.21203/rs.3.rs-103859/v1

12. Bontempi, E. 2020. The Europe second wave of COVID-19 infection and the Italy "strange" $\quad$ situation. Environmental Research, p.110476. https://dx.doi.org/10.1016\%2Fj.envres.2020.110476

13. Business Today. 2020. https://www.businesstoday.in/current/economy-politics/indiaannounces-rs-900-crore-for-covid-19-vaccine-research/story/421802.html.

14. Byanaku, A., and Ibrahim, M. 2020. Knowledge, attitudes, and practices (KAP) towards COVID-19: A quick online cross-sectional survey among Tanzanian residents. medRxiv. https://doi.org/10.1101/2020.04.26.20080820

15. CDC, 2020. $\quad$ https://www.cdc.gov/coronavirus/2019-ncov/daily-lifecoping/pets.html\#: :text=A\%20small\%20number\%20of\%20pets,is\%20considered\%20to \%20be\%201ow.

16. CNBC, 2020. https://www.cnbctv18.com/healthcare/covid-19-the-second-pandemicwave-has-hit-these-countries-hard-7364651.htm 
17. Cobey, K.D., Stulp, G., Laan, F., Buunk, A.P., Pollet, T.V. 2013. Sex differences in risk taking behavior among Dutch cyclists. Evol Psychol. 11: 350-64. https://doi.org/10.1177\%2F147470491301100206

18. Coustasse, A., Kimble, C. and Maxik, K. 2021. COVID-19 and Vaccine Hesitancy: A Challenge the United States Must Overcome. The Journal of Ambulatory Care Management, 44(1), pp.71-75. https://doi.org/10.1097/jac.0000000000000360

19. Dahab, M., van Zandvoort, K., Flasche, S., Warsame, A., Spiegel, P. B., Waldman, J., \& Checchi, F. 2020. COVID-19 control in low-income settings and displaced populations: What can realistically be done? https://www.lshtm.ac.uk/newsevents/news/2020/covid-19control-low-income-settings anddisplaced-populations-what-can

20. Fisher, W.A., Fisher, J.D., Rye, B.J. 1995. Understanding and promoting AIDS-preventive behavior: insights from the theory of reasoned action. Heal Psychol 14:255-64. https://doi.org/10.1037//0278-6133.14.3.255.

21. Haque, T., Hossain, K.M., Bhuiyan, M.M.R., Ananna, S.A., Chowdhury, S.H., Islam, M.R., Ahmed, A. and Rahman, M.M., 2020. Knowledge, attitude and practices (KAP) towards COVID-19 and assessment of risks of infection by SARS-CoV-2 among the Bangladeshi population: An online cross sectional survey. https://doi.org/10.21203/rs.3.rs$\underline{24562 / v 1}$

22. Hindustan Times, 2020. https://www.hindustantimes.com/india-news/india-s-covid-19tests-per-day-highest-in-the-world-says-health-ministry/storyeip0z18Jico71uQFIoODAJ.html

23. Hussain, A., Garima, T., Singh, B.M., Ram, R. and Tripti, R.P., 2020. Knowledge, attitudes, and practices towards COVID-19 among Nepalese Residents: A quick online 
cross-sectional survey. Asian Journal of Medical Sciences, 11(3), pp.6-11. http://orcid.org/0000-0001-6218-0500

24. Ioannidis, J.P.A. 2020. Coronavirus disease 2019: The harms of exaggerated information and nonevidence- based measures. European Journal of Clinical Investigation, e13223. https://doi.org/10.1111/eci.13223

25. Isah, M.B., Abdulsalam, M., Bello, A., Ibrahim, M.I., Usman, A., Nasir, A., Abdulkadir, B., Usman, A.R., Matazu, K.I., Sani, A. and Shuaibu, A. 2020. Corona Virus Disease 2019 (COVID-19): Knowledge, attitudes, practices (KAP) and misconceptions in the general population of Katsina $\quad$ State, $\quad$ Nigeria. medRxiv. https://doi.org/10.1101/2020.06.11.20127936

26. Jones, T.L., Baxter, M.A., Khanduja, V. 2013. A quick guide to survey research. Ann $R$ Coll Surg Engl. 95(1):5-7. https://doi.org/10.1308/003588413X13511609956372 PMID: 23317709

27. Kakemam, E., Ghoddoosi-Nejad, D., Chegini, Z., Momeni, K., Salehinia, H., Hassanipour, S., Ameri, H. and Arab-Zozani, M., 2020. Knowledge, attitudes, and practices among the general population during COVID-19 outbreak in Iran: A national cross-sectional survey. medRxiv. https://doi.org/10.1101/2020.06.10.20127258

28. Konwarh, R., 2020a. Can CRISPR/cas technology be a felicitous stratagem against the COVID-19 Fiasco? prospects and hitches. Frontiers in molecular biosciences, 7. 557377 https://doi.org/10.3389/fmolb.2020.557377

29. Konwarh, R., 2020b. Nanobodies: prospects of expanding the gamut of neutralizing antibodies against the novel coronavirus, SARS-CoV-2. Frontiers in Immunology, 11. 1531. https://doi.org/10.3389/fimmu.2020.01531 
30. Le, T.T., Andreadakis, Z., Kumar, A., Roman, R.G., Tollefsen, S., Saville, M. and Mayhew, S., 2020. The COVID-19 vaccine development landscape. Nat Rev Drug Discov, 19(5), pp.305-306. https://doi.org/10.1038/d41573-020-00073-5

31. LGH. 2020. Lancet Glob Health, Redefining vulnerability in the era of COVID-19. [editorial] The Lancet 395(10230): P1089. https://doi.org/10.1016/S0140-6736(20)307571

32. Li, J. Y., You, Z., Wang, Q., et al. 2020. The epidemic of 2019-novel-coronavirus (2019$\mathrm{nCoV})$ pneumonia and insights for emerging infectious diseases in the future. Microbes and Infection, 22(2): 80-85. https://doi.org/10.1016/j.micinf.2020.02.002

33. Mousa, K.N.A.A., Saad, M.M.Y. and Abdelghafor, M.T.B., 2020. Knowledge, attitudes, and practices surrounding COVID-19 among Sudan citizens during the pandemic: an online cross-sectional study. Sudan Journal of Medical Sciences (SJMS). https://doi.org/10.18502/sjms.v15i5.7176

34. Olapegba, P. O., Ayandele, O., Kolawole, S. O., Oguntayo, R., Gandi, J. C., Dangiwa, A. L., Ottu, I. F. \& Iorfa, S. K. 2020. A Preliminary Assessment of Novel Coronavirus (COVID-19) Knowledge and Perceptions in Nigeria. MedRxiv. https://doi.org/10.1101/2020.04.11.20061408

35. Pawlowski, B., Atwal, R., Dunbar, R. 2008. Sex Differences in Everyday Risk-Taking Behavior in Humans. Evolutionary Psychology. 6: 29-42. https://doi.org/10.1177\%2F147470490800600104

36. Pedro, S.A., Ndjomatchoua, F.T., Jentsch, P., Tchuenche, J.M., Anand, M., and Bauch, C.T. 2020. Conditions for a Second Wave of COVID-19 Due to Interactions Between 
Disease Dynamics and Social Processes. Frontiers in Physics, 8:574514. http://dx.doi.org/10.3389/fphy.2020.574514

37. Rampal, 2020. https://www.indiatoday.in/diu/story/lockdown-coronavirus-spread-studyindia-1681034-2020-05-23

38. Roy, D., Tripathy, S., Kar, S.K., Sharma, N., Verma, S.K. and Kaushal, V. 2020. Study of knowledge, attitude, anxiety \& perceived mental healthcare need in Indian population during COVID-19 pandemic. Asian Journal of Psychiatry, p.102083. https://dx.doi.org/10.1016\%2Fj.ajp.2020.102083

39. Shimizu, K. 2020. 2019-nCoV, fake news, and racism. The Lancet, 395(10225):685-686. https://doi.org/10.1016/S0140-6736(20)30357-3

40. Srichan, P., Apidechkul, T., Tamornpark, R., Yeemard, F., Khunthason, S., Kitchanapaiboon, S., Wongnuch, P., Wongphaet, A. and Upala, P. 2020. Knowledge, Attitude and Preparedness to Respond to the 2019 Novel Coronavirus (COVID-19) Among the Bordered Population of Northern Thailand in the Early Period of the Outbreak: A Cross-Sectional Study. https://apps.who.int/iris/handle/10665/334195

41. The Hindu. 2020. https://www.thehindu.com/news/national/vande-bharat-mission-set-tobreak-evacuation-record/article31751772.ece\#: :text=337\%20commercial\%20flights.,A\%20total\%20of\%203\%2C48\%2C565\%20citizens\%20have\%20registered\%20till\%20n ow,External\%20Affairs\%20said\%20on\%20Thursday,

42. van de Mortel, T.F. 2008. Faking it: social desirability response bias in self-report research. Australian Journal of Advanced Nursing, 25(4): 40-48.

43. Walker, P., Whittaker C., Watser, O., et al 2020. The Global Impact of COVID-19 and Strategies for Mitigation and Suppression. WHO Collaborating Centre for Infectious 
Disease Modelling, MRC Centre for Global Infectious Disease Analysis, Abdul Latif Jameel Institute for Disease and Emergency Analytics, Imperial College London. https://www.imperial.ac.uk/media/imperial

college/medicine/sph/ide/gidafellowships/Imperial-College-COVID19-Global-Impact 2603-2020.pdf

44. Wenham, C., Smith, J., \& Morgan, R. 2020. COVID-19: The gendered impacts of the outbreak. The Lancet, 395(10227), 846-848. https://doi.org/10.1016/S0140$6736(20) 30526-2$

45. WHO, 2020. Director-General's opening remarks at the media briefing on COVID-19 11 March 2020. Retrieved April 4, 2020, from https://www.who.int/dg/speec hes/detai 1/who-directorgener al-s-opening-remar ks-at-the-media -briefing-on-covid -19-11-march $-2020)$.

46. Xu, S., and Li, Y. 2020. Beware of the second wave of COVID-19. The Lancet, 395(10233): 1321-1322. https://doi.org/10.1016/S0140-6736(20)30845-X

47. Zhong, B.L., Luo, W., Li, H.M., Zhang, Q.Q., Liu, X.G., Li, W.T. and Li, Y., 2020. Knowledge, attitudes, and practices towards COVID-19 among Chinese residents during the rapid rise period of the COVID-19 outbreak: a quick online cross-sectional survey. International journal of biological sciences, 16(10): 1745. https://dx.doi.org/10.7150\%2Fijbs.45221 
Table 1. Demographic characteristics of participants $(n=566)$

\begin{tabular}{llll}
\hline Demographic characteristics & $\mathrm{n}$ & $\%$ \\
\hline Gender & Male & 287 & 50.71 \\
& Female & 279 & 49.29 \\
& $15-29$ & 408 & 72.08 \\
& $30-49$ & 153 & 27.03 \\
\multirow{5}{*}{ Marital status } & $50-69$ & 3 & 0.53 \\
& $>70$ & 2 & 0.35 \\
Education & Married & 143 & 25.27 \\
status & Unmarried & 422 & 74.56 \\
& Others (Divorced) & 1 & 0.18 \\
& <12 & 27 & 4.77 \\
Occupation & UG (holding or pursuing) & 206 & 36.40 \\
& PG (holding or pursuing) & 217 & 38.34 \\
& Ph.D. (holding or pursuing) & 116 & 20.49 \\
& Student & 315 & 55.65 \\
& Private job & 151 & 26.68 \\
& Government Job & 45 & 7.95 \\
& Health workers & 17 & 3.00 \\
& Others (self, unemployed) & 38 & 6.71 \\
\hline
\end{tabular}


Table 2. Knowledge and awareness of Indians towards COVID-19 ( $n=566)$

\begin{tabular}{llll}
\hline \multirow{2}{*}{ Knowledge questionnaires } & \multicolumn{2}{l}{ Frequencies (\%) } \\
\cline { 3 - 4 } K1 & Expansion of the COVID-19. & Correct & Incorrect \\
K2 & Where was the first case of COVID-19 reported globally? & $387(68.4)$ & $179(31.6)$ \\
K3 & In which state was the first case of COVID-19 reported in India? & $541(95.6)$ & $25(4.4)$ \\
K4 & Which virus causes COVID-19? & $450(79.5)$ & $116(20.5)$ \\
K5 & How does COVID-19 spread mainly? & $345(61.0)$ & $221(39.0)$ \\
K6 & Pet animals can spread COVID-19. & $518(91.5)$ & $48(8.5)$ \\
K7 & Select the three main symptoms of COVID-19. & $371(65.5)$ & $195(34.5)$ \\
K8 & For how many days are suspected people isolated and observed in quarantine? & $503(88.9)$ & $63(11.1)$ \\
K9 & What is the Mortality rate (death rate) associated with COVID-19 worldwide? & $559(98.8)$ & $7(1.2)$ \\
K10 & What is the Mortality rate (death rate) associated with COVID-19 in India? & $377(66.6)$ & $189(33.4)$ \\
K11 & What is the recommended minimal social distancing norms (in feet) to prevent & $406(71.7)$ & $160(28.3)$ \\
& COVID-19's spread? & $352(62.2)$ & $214(37.8)$ \\
K12 & How many seconds are suggested to clean your hands with soap to prevent COVID- & $485(85.7)$ & $81(14.3)$ \\
& 19's spread? & & \\
K13 & Which is the best preventive measure for COVID-19? & $305(53.9)$ & $261(46.1)$ \\
K14 & If you have only one new nose mask, whom would you give the mask to wear? & $348(61.5)$ & $218(57.4)$ \\
K15 & Effective treatment is available for COVID-19. & $402(71.0)$ & $164(29.0)$ \\
K16 & We cannot prevent COVID-19's spreading. & $437(77.2)$ & $129(22.8)$ \\
K17 & Vaccines are not available for COVID-19 at the moment. & $517(91.3)$ & $49(8.7)$ \\
K18 & What is the genetic material of COVID-19 virus? & $427(75.4)$ & $139(24.6$ \\
\hline
\end{tabular}


Table 3. Attitudes of Indians towards COVID-19 ( $\mathrm{n}=566)$

\begin{tabular}{|c|c|c|c|c|c|c|c|c|c|c|c|c|c|c|}
\hline \multicolumn{2}{|c|}{ Attitude questionnaires } & \multicolumn{2}{|c|}{ Strongly disagree (1) } & \multicolumn{2}{|c|}{ Disagree (2) } & \multicolumn{2}{|c|}{ Neutral (3) } & \multicolumn{2}{|c|}{ Agree (4) } & \multicolumn{2}{|c|}{ Strongly agree (5) } & \multirow{2}{*}{$\begin{array}{l}\text { Average } \\
\text { score }\end{array}$} & \multirow[t]{2}{*}{ SD } & \multirow[t]{2}{*}{$p$-value } \\
\hline & & $\mathrm{n}$ & $\%$ & $\mathrm{n}$ & $\%$ & 37 & $\%$ & $\mathrm{n}$ & $\%$ & $\mathrm{n}$ & $\%$ & & & \\
\hline A1 & $\begin{array}{l}\text { You think COVID-19 is a serious public health } \\
\text { threat. }\end{array}$ & 12 & 2.1 & 8 & 1.4 & 131 & 6.5 & 111 & 19.6 & 398 & 70.3 & 4.55 & 0.72 & $<0.001 * * *$ \\
\hline A2 & $\begin{array}{l}\text { People are panicked in India about COVID-19, } \\
\text { including my self }\end{array}$ & 21 & 3.7 & 34 & 6.0 & 82 & 23.1 & 234 & 41.3 & 146 & 25.8 & 3.80 & 1.02 & $<0.001 * * *$ \\
\hline A3 & $\begin{array}{l}\text { The Indian government is putting up a great } \\
\text { effort in controlling the spread of COVID- } 19 \text {. }\end{array}$ & 14 & 2.5 & 21 & 3.7 & 76 & 14.5 & 175 & 30.9 & 274 & 48.4 & 4.19 & 0.96 & $<0.001 * * *$ \\
\hline A4 & $\begin{array}{l}\text { Indians will win the battle against the COVID- } \\
19 \text { virus. }\end{array}$ & 13 & 2.3 & 14 & 2.5 & 74 & 13.4 & 166 & 29.3 & 297 & 52.5 & 4.27 & 0.89 & $<0.001 * * *$ \\
\hline A5 & $\begin{array}{l}\text { Traveling is a prime reason for contracting } \\
\text { COVID-19. }\end{array}$ & 25 & 4.4 & 27 & 4.8 & 96 & 13.1 & 171 & 30.2 & 269 & 47.5 & 4.12 & 1.18 & $<0.001 * * *$ \\
\hline A6 & $\begin{array}{l}\text { Patients recovered from COVID-19 can be } \\
\text { allowed into the society. }\end{array}$ & 39 & 6.9 & 55 & 9.7 & 155 & 17.0 & 145 & 25.6 & 231 & 40.8 & 3.84 & 1.56 & $<0.001 * * *$ \\
\hline A7 & I am thinking about COVID-19 all day. & 97 & 17.1 & 128 & 22.6 & 156 & 27.4 & 106 & 18.7 & 80 & 14.1 & 2.90 & 1.65 & 0.054 \\
\hline A8 & I am worried about contracting COVID-19. & 49 & 8.7 & 83 & 14.7 & 134 & 27.6 & 171 & 30.2 & 107 & 18.9 & 3.36 & 1.42 & $<0.001 * * *$ \\
\hline A9 & $\begin{array}{l}\text { My daily life is spoiled due to COVID-19 } \\
\text { outbreak. }\end{array}$ & 47 & 8.3 & 75 & 13.3 & 18 & 23.7 & 135 & 23.9 & 175 & 30.9 & 3.56 & 1.63 & $<0.001 * * *$ \\
\hline A10 & $\begin{array}{l}\text { If I have symptoms of COVID-19, I will isolate } \\
\text { myself. }\end{array}$ & 13 & 2.3 & 8 & 1.4 & 194 & 3.2 & 42 & 7.4 & 485 & 85.7 & 4.73 & 0.62 & $<0.001 * * *$ \\
\hline A11 & $\begin{array}{l}\text { COVID-19 is caused by a synthetic virus (man- } \\
\text { made). }\end{array}$ & 79 & 14.0 & 56 & 9.9 & 191 & 34.3 & 114 & 20.1 & 123 & 21.7 & 3.26 & 1.66 & $<0.001 * * *$ \\
\hline A12 & The virus, causing COVID-19 is a bio-weapon. & 68 & 12.0 & 47 & 8.3 & 94 & 33.7 & 134 & 23.7 & 126 & 22.3 & 3.36 & 1.56 & $<0.001 * * *$ \\
\hline A13 & $\begin{array}{l}\text { Indian government's suggestion to support the } \\
\text { healthcare workers (physician, nurse, } \\
\text { pharmacist, lab assistants) by clapping on } 22 \text { nd } \\
\text { March, } 2020 \text { during COVID-19 lock-down is } \\
\text { appreciable. }\end{array}$ & 44 & 7.8 & 35 & 6.2 & 112 & 16.6 & 139 & 24.6 & 254 & 44.9 & 3.93 & 1.56 & $<0.001 * * *$ \\
\hline A14 & $\begin{array}{l}\text { Indian government's call to display our } \\
\text { collective strength to defeat COVID-19 by } \\
\text { lighting lamps on 5th April } 2020 \text { was } \\
\text { encouraging. }\end{array}$ & 68 & 12.0 & 50 & 8.8 & & 19.8 & 123 & 21.7 & 213 & 37.6 & 3.64 & 1.88 & $<0.001 * * *$ \\
\hline
\end{tabular}

0 


\begin{tabular}{|c|c|c|c|c|c|c|c|c|c|c|}
\hline \multicolumn{2}{|c|}{ Practice questionnaires } & \multicolumn{2}{|c|}{ Never (1) } & \multicolumn{2}{|c|}{ Sometimes (2) } & \multicolumn{2}{|c|}{ Always (3) } & \multirow{2}{*}{$\begin{array}{l}\text { Average } \\
\text { score }\end{array}$} & \multirow[t]{2}{*}{ SD } & \multirow[t]{2}{*}{$p$-value } \\
\hline & & $\mathrm{n}$ & $\%$ & $\mathrm{n}$ & $\%$ & $\mathrm{n}$ & $\%$ & & & \\
\hline $\mathrm{P} 1$ & $\begin{array}{l}\text { Are you wearing a nose mask when you go out during } \\
\text { the COVID-19 outbreak? }\end{array}$ & 34 & 6.0 & 39 & 6.9 & 493 & 87.1 & 2.81 & 0.27 & $<0.001 * * *$ \\
\hline P2 & $\begin{array}{l}\text { Are you carrying sanitizer during the COVID-19 } \\
\text { outbreak? }\end{array}$ & 45 & 8.0 & 107 & 18.9 & 414 & 73.1 & 2.65 & 0.39 & $<0.001 * * *$ \\
\hline P3 & $\begin{array}{l}\text { Are you maintaining social distance during the } \\
\text { COVID-19 outbreak? }\end{array}$ & 32 & 5.7 & 49 & 8.7 & 485 & 85.7 & 2.80 & 0.27 & $<0.001 * * *$ \\
\hline P4 & $\begin{array}{l}\text { Do you wash your hands after returning from outside } \\
\text { during the COVID-19 outbreak? }\end{array}$ & 30 & 5.3 & 24 & 4.2 & 512 & 90.5 & 2.85 & 0.23 & $<0.001 * * *$ \\
\hline P5 & $\begin{array}{l}\text { Are you avoiding crowded places (worship places, bus, } \\
\text { and train stations, mall, bank, functions, etc.) these } \\
\text { days? }\end{array}$ & 38 & 6.7 & 43 & 7.6 & 485 & 85.7 & 2.79 & 0.30 & $<0.001 * * *$ \\
\hline P6 & $\begin{array}{l}\text { Are you willing to attend functions during the COVID- } \\
19 \text { outbreak? }\end{array}$ & 436 & 77.0 & 65 & 11.5 & 65 & 11.5 & 1.34 & 0.46 & $<0.001 * * *$ \\
\hline P7 & $\begin{array}{l}\text { Do you prefer to shake hand when you greet your } \\
\text { friends during the COVID-19 outbreak? }\end{array}$ & 462 & 81.6 & 51 & 9.0 & 53 & 9.4 & 1.28 & 0.39 & $<0.001 * * *$ \\
\hline P8 & $\begin{array}{l}\text { Are you supporting lockdown in India to control the } \\
\text { COVID-19? }\end{array}$ & 34 & 6.0 & 91 & 16.1 & 441 & 77.9 & 2.72 & 0.32 & $<0.001 * * *$ \\
\hline
\end{tabular}

***Statistically significant at $\mathrm{p}<0.001$ (chi-square analysis) 
Table 5. Distribution of KAP scores among demographic variables of Indians towards COVID-19.

\begin{tabular}{|c|c|c|c|c|c|c|c|c|c|c|c|c|c|}
\hline \multicolumn{2}{|c|}{ Demographic characteristics } & \multicolumn{2}{|c|}{$\begin{array}{l}\text { Knowledge score } \\
\quad(\text { mean } \pm \text { SD })\end{array}$} & \multirow{2}{*}{$\begin{array}{l}F \text {-value } \\
0.50\end{array}$} & \multirow{2}{*}{$\begin{array}{l}P \text {-value } \\
0.48\end{array}$} & \multicolumn{2}{|c|}{$\begin{array}{l}\text { Attitude score } \\
(\text { mean } \pm \text { SD })\end{array}$} & \multirow{2}{*}{$\begin{array}{l}\text { F-value } \\
1.14\end{array}$} & \multirow{2}{*}{$\begin{array}{c}P \text {-value } \\
0.29\end{array}$} & \multicolumn{2}{|c|}{$\begin{array}{c}\text { Practice score } \\
(\text { mean } \pm S D)\end{array}$} & \multirow{2}{*}{$\frac{F \text {-value }}{2.51}$} & \multirow{2}{*}{$\begin{array}{r}p \text {-value } \\
0.11\end{array}$} \\
\hline Gender & Male & 13.7 & 2.7 & & & 3.53 & 0.46 & & & 2.72 & 0.46 & & \\
\hline & Female & 13.6 & 2.7 & & & 3.57 & 0.44 & & & 2.78 & 0.41 & & \\
\hline \multirow[t]{4}{*}{ Age } & $15-29$ & 13.5 & 2.8 & 3.49 & $0.016^{*}$ & 3.54 & 0.45 & 0.38 & 0.769 & 2.72 & 0.46 & 2.82 & $0.038^{*}$ \\
\hline & $30-49$ & 14.1 & 2.3 & & & 3.57 & 0.44 & & & 2.83 & 0.35 & & \\
\hline & $50-69$ & 12.7 & 2.5 & & & 3.40 & 0.04 & & & 2.96 & 0.07 & & \\
\hline & $>70$ & 10.0 & 1.4 & & & 3.71 & 0.71 & & & 2.44 & 0.62 & & \\
\hline \multirow[t]{3}{*}{ Marital status } & Married & 13.9 & 2.4 & 1.61 & 0.205 & 3.56 & 0.46 & 0.08 & 0.78 & 2.81 & 0.38 & 3.18 & 0.075 \\
\hline & Unmarried & 13.3 & 2.9 & & & 3.55 & 0.45 & & & 2.73 & 0.45 & & \\
\hline & Others (Divorced) & 15.0 & NA & & & 3.36 & NA & & & 2.88 & NA & & \\
\hline \multirow[t]{4}{*}{ Education status ${ }^{1}$} & $<12^{\text {th }}$ grade & 12.9 & 2.9 & 6.99 & $<0.001^{*}$ & 3.61 & 0.44 & 2.20 & 0.087 & 2.69 & 0.48 & 1.00 & 0.392 \\
\hline & UG & 13.0 & 2.9 & & & 3.59 & 0.45 & & & 2.72 & 0.43 & & \\
\hline & PG & 14.1 & 2.7 & & & 3.56 & 0.45 & & & 2.77 & 0.46 & & \\
\hline & Ph.D. & 14.1 & 2.1 & & & 3.46 & 0.44 & & & 2.79 & 0.37 & & \\
\hline \multirow[t]{5}{*}{ Occupation } & Student & 13.7 & 2.8 & 1.26 & 0.285 & 3.56 & 0.45 & 0.23 & 0.916 & 2.72 & 0.46 & 1.48 & 0.205 \\
\hline & Private job & 13.6 & 2.5 & & & 3.55 & 0.47 & & & 2.77 & 0.41 & & \\
\hline & Government Job & 14.3 & 2.9 & & & 3.50 & 0.39 & & & 2.85 & 0.31 & & \\
\hline & Health workers ${ }^{2}$ & 13.4 & 2.5 & & & 3.54 & 0.26 & & & 2.88 & 0.20 & & \\
\hline & Others (self, unemployed) & 13.0 & 2.2 & & & 3.55 & 0.48 & & & 2.70 & 0.50 & & \\
\hline \multirow[t]{8}{*}{ State } & $\mathrm{A} \& \mathrm{NI}^{3}$ & 14.3 & 3.2 & 2.26 & $0.007 * *$ & 3.88 & 0.18 & 0.97 & 0.484 & 3.00 & 0.00 & 3.04 & $<0.001 * * *$ \\
\hline & Andhra Pradesh & 13.1 & 2.7 & & & 3.57 & 0.51 & & & 2.73 & 0.43 & & \\
\hline & Assam & 14.1 & 2.6 & & & 3.58 & 0.38 & & & 2.83 & 0.40 & & \\
\hline & Bihar & 15.5 & 0.7 & & & 3.57 & 0.40 & & & 2.00 & 1.24 & & \\
\hline & Chhattisgarh & 17.0 & NA & & & 4.07 & NA & & & 3.00 & NA & & \\
\hline & Delhi & 14.0 & 1.0 & & & 3.55 & 0.27 & & & 3.00 & 0.00 & & \\
\hline & Goa & 15.5 & 0.7 & & & 3.43 & 0.20 & & & 3.00 & 0.00 & & \\
\hline & Gujarat & 15.0 & 2.8 & & & 3.25 & 0.05 & & & 2.75 & 0.18 & & \\
\hline
\end{tabular}




\begin{tabular}{|c|c|c|c|c|c|c|c|}
\hline & Haryana & 14.0 & 0.0 & 3.64 & 0.61 & 2.94 & 0.09 \\
\hline & Jharkhand & 12.2 & 1.9 & 3.44 & 0.31 & 2.90 & 0.10 \\
\hline & Karnataka & 13.8 & 2.3 & 3.29 & 0.50 & 2.50 & 0.69 \\
\hline & Kerala & 14.9 & 2.6 & 3.40 & 0.35 & 2.82 & 0.20 \\
\hline & Madhya Pradesh & 12.0 & NA & 3.79 & NA & 3.00 & NA \\
\hline & Maharashtra & 14.1 & 2.5 & 3.58 & 0.29 & 2.91 & 0.19 \\
\hline & Manipur & 15.0 & NA & 3.93 & NA & 3.00 & NA \\
\hline & Odisha & 14.0 & 3.3 & 3.56 & 0.68 & 2.98 & 0.05 \\
\hline & Puducherry & 15.0 & NA & 3.50 & NA & 3.00 & NA \\
\hline & Punjab & 10.0 & NA & 3.21 & NA & 2.88 & NA \\
\hline & Rajasthan & 15.5 & 0.6 & 3.80 & 0.32 & 2.94 & 0.13 \\
\hline & Tamil Nadu & 13.0 & 2.9 & 3.53 & 0.52 & 2.64 & 0.47 \\
\hline & Telangana & 14.5 & 2.2 & 3.67 & 0.30 & 2.77 & 0.27 \\
\hline & Tripura & 14.0 & NA & 3.14 & NA & 3.00 & NA \\
\hline & Uttar Pradesh & 15.2 & 0.8 & 3.23 & 0.75 & 2.53 & 0.86 \\
\hline & Uttarakhand & 12.0 & NA & 3.93 & NA & 2.88 & NA \\
\hline & West Bengal & 13.9 & 2.4 & 3.50 & 0.36 & 2.96 & 0.06 \\
\hline Overall average \pm SI & D (Min-Max) & $13.6=$ & $2.7(2-18)$ & $3.53 \pm$ & $.45(1.43-4.43)$ & 2.75 & $0.43(1-3)$ \\
\hline
\end{tabular}

$*, * *, * * *$ Statistically significant at $\mathrm{p}<0.05, \mathrm{p}<0.01$, and $\mathrm{p}<0.001$, respectively (ANOVA analysis); ${ }^{1}$ holding or pursuing; ${ }^{2}$ Healthcare workers (nurse, physician, pharmacist, lab assistant); ${ }^{3}$ Andaman and Nicobar Islands. 
19 Table 6. Comparisons of demographic characteristics by knowledge, attitudes, and practices skills of Indians towards COVID-19 (n=566)

\begin{tabular}{|c|c|c|c|c|c|c|c|c|c|c|c|c|c|c|c|c|c|c|c|c|c|c|}
\hline \multirow{3}{*}{\multicolumn{2}{|c|}{ Demographic characteristics }} & \multicolumn{6}{|c|}{ Knowledge score (mean \pm SD) } & \multirow{3}{*}{$\begin{array}{c}\left(X^{2}\right) \\
p \text {-value }\end{array}$} & \multicolumn{6}{|c|}{ Attitude score (mean $\pm \mathrm{SD})$} & \multirow{3}{*}{$\begin{array}{c}\left(X^{2}\right) \\
p \text {-value }\end{array}$} & \multicolumn{6}{|c|}{ Practice score (mean \pm SD) } & \multirow{3}{*}{$\begin{array}{c}\left(X^{2}\right) \\
p \text {-value }\end{array}$} \\
\hline & & \multicolumn{2}{|c|}{ Poor } & \multicolumn{2}{|c|}{ Moderate } & \multicolumn{2}{|c|}{ Good } & & \multicolumn{2}{|c|}{ Poor } & \multicolumn{2}{|c|}{ Moderate } & \multicolumn{2}{|c|}{ Good } & & \multicolumn{2}{|c|}{ Poor } & \multicolumn{2}{|c|}{ Moderate } & \multicolumn{2}{|c|}{ Good } & \\
\hline & & $\mathrm{n}$ & $\%$ & $\mathrm{n}$ & $\%$ & $\mathrm{n}$ & $\%$ & & $\mathrm{n}$ & $\%$ & $\mathrm{n}$ & $\%$ & $\mathrm{n}$ & $\%$ & & $\mathrm{n}$ & $\%$ & $\mathrm{n}$ & $\%$ & $\mathrm{n}$ & $\%$ & \\
\hline \multirow[t]{2}{*}{ Gender } & Male & 24 & 8.4 & 185 & 64.5 & 78 & 27.2 & \multirow{2}{*}{$\begin{array}{l}(0.043) \\
0.979\end{array}$} & 5 & 1.7 & 271 & 94.4 & 11 & 3.8 & \multirow{2}{*}{$\begin{array}{l}(3.16) \\
0.206\end{array}$} & 13 & 4.5 & 43 & 15.0 & 231 & 80.5 & \multirow{2}{*}{$\begin{array}{l}(2.08) \\
0.354\end{array}$} \\
\hline & Female & 23 & 8.2 & 178 & 63.8 & 78 & 28.0 & & 5 & 1.8 & 270 & 96.8 & 4 & 1.4 & & 11 & 3.9 & 31 & 11.1 & 237 & 84.9 & \\
\hline \multirow[t]{4}{*}{ Age } & $15-29$ & 41 & 10.0 & 255 & 62.5 & 112 & 27.5 & \multirow{4}{*}{$\begin{array}{l}(13.31) \\
0.033^{*}\end{array}$} & 8 & 2.0 & 391 & 95.8 & 9 & 2.2 & \multirow{4}{*}{$\begin{array}{l}(1.75) \\
0.468\end{array}$} & 20 & 4.9 & 62 & 15.2 & 326 & 79.9 & (13.66) \\
\hline & $30-49$ & 5 & 3.3 & 105 & 68.6 & 43 & 28.1 & & 2 & 1.3 & 145 & 94.8 & 6 & 3.9 & & 2 & 1.3 & 11 & 7.2 & 138 & 90.2 & $0.005^{* *}$ \\
\hline & $50-69$ & 0 & 0.0 & 3 & 100.0 & 0 & 0.0 & & 0 & 0.0 & 3 & 100.0 & 0 & 0.0 & & 0 & 0.0 & 0 & 0.0 & 3 & 100.0 & \\
\hline & $>70$ & 1 & 50.0 & 1 & 50.0 & 0 & 0.0 & & 0 & 0.0 & 2 & 100.0 & 0 & 0.0 & & 0 & 0.0 & 1 & 50.0 & 1 & 50.0 & \\
\hline Marital & Married & 8 & 5.6 & 98 & 68.5 & 37 & 25.9 & $(2.42)$ & 3 & 2.1 & 135 & 94.4 & 5 & 3.5 & $(0.65)$ & 4 & 2.8 & 15 & 10.5 & 124 & 86.7 & $(2.32)$ \\
\hline status & Unmarried & 39 & 9.2 & 265 & 62.8 & 118 & 28.0 & 0.298 & 7 & 1.7 & 405 & 96.0 & 10 & 2.4 & 0.721 & 20 & 4.7 & 59 & 14.0 & 343 & 81.3 & 0.312 \\
\hline Education & $<12^{\text {th }}$ grade & 6 & 22.2 & 16 & 59.3 & 5 & 18.5 & (22.32) & 0 & 0.0 & 26 & 96.3 & 1 & 3.7 & $(3.40)$ & 2 & 7.4 & 5 & 18.5 & 20 & 74.1 & (7.96) \\
\hline status $^{1}$ & UG & 21 & 10.2 & 141 & 68.4 & 44 & 21.4 & $0.003 * *$ & 4 & 1.9 & 194 & 94.2 & 8 & 3.9 & 0.396 & 8 & 3.9 & 35 & 17.0 & 163 & 79.1 & 0.117 \\
\hline & PG & 17 & 7.8 & 125 & 57.6 & 75 & 34.6 & & 4 & 1.8 & 208 & 95.9 & 5 & 2.3 & & 11 & 5.1 & 21 & 9.7 & 185 & 85.3 & \\
\hline & Ph.D. & 3 & 2.6 & 82 & 70.7 & 31 & 26.7 & & 2 & 1.7 & 113 & 97.4 & 1 & 0.9 & & 3 & 2.6 & 13 & 11.2 & 100 & 86.2 & \\
\hline Occupation & Student & 32 & 10.2 & 186 & 59.0 & 97 & 30.8 & $(16.55)$ & 6.0 & 1.9 & 301.0 & 95.6 & 8 & 2.5 & $(2.38)$ & 16 & 5.1 & 45 & 14.3 & 254 & 80.6 & $(2.38)$ \\
\hline & Private job & 8 & 5.3 & 111 & 73.5 & 32 & 21.2 & $0.035^{*}$ & 3.0 & 2.0 & 144.0 & 95.4 & 4 & 2.7 & 0.967 & 5 & 3.3 & 18 & 11.9 & 128 & 84.8 & 0.760 \\
\hline & Government Job & 3 & 6.7 & 25 & 55.6 & 17 & 37.8 & & 0.0 & 0.0 & 43.0 & 95.6 & 2 & 4.4 & & 1 & 2.2 & 3 & 6.7 & 41 & 91.1 & \\
\hline & Health workers ${ }^{2}$ & 1 & 5.9 & 12 & 70.6 & 4 & 23.5 & & 0.0 & 0.0 & 17.0 & 100.0 & 0 & 0.0 & & 0 & 0.0 & 2 & 11.8 & 15 & 88.2 & \\
\hline & Others $^{3}$ & 3 & 7.9 & 30 & 78.9 & 5 & 13.2 & & 1.0 & 2.6 & 36.0 & 94.7 & 1 & 2.6 & & 2 & 5.3 & 6 & 15.8 & 30 & 79.0 & \\
\hline State & $\mathrm{A} \& \mathrm{NI}^{4}$ & 0 & 0.0 & 2 & 66.7 & 1 & 33.3 & (22.67) & 0 & 0.0 & 3 & 100.0 & 0 & 0.0 & (35.23) & 0 & 0.0 & 3 & 100.0 & 0 & 0.0 & (77.10) \\
\hline & Andhra Pradesh & 1 & 10.0 & 7 & 70.0 & 2 & 20.0 & 0.693 & 0 & 0.0 & 9 & 90.0 & 1 & 10.0 & 0.107 & 0 & 0.0 & 3 & 30.0 & 7 & 70.0 & $<0.001 * *$ \\
\hline & Assam & 13 & 5.7 & 144 & 62.6 & 73 & 31.7 & & 0 & 0.0 & 226 & 98.3 & 4 & 1.7 & & 9 & 3.9 & 11 & 4.8 & 210 & 91.3 & \\
\hline & Delhi & 0 & 0.0 & 3 & 100.0 & 0 & 0.0 & & 0.0 & 0.0 & 3.0 & 100.0 & 0 & 0.0 & & 0 & 0.0 & 0 & 0.0 & 3 & 100.0 & \\
\hline & Jharkhand & 0 & 0.0 & 5 & 100.0 & 0 & 0.0 & & 0.0 & 0.0 & 5 & 100.0 & 0 & 0.0 & & 0 & 0.0 & 0 & 0.0 & 5 & 100.0 & \\
\hline & Karnataka & 1 & 9.1 & 7 & 63.6 & 3 & 27.3 & & 1 & 9.1 & 10 & 90.9 & 0 & 0.0 & & 2 & 18.2 & 2 & 18.2 & 7 & 63.6 & \\
\hline & Kerala & 0 & 0.0 & 5 & 55.6 & 4 & 44.4 & & 0 & 0.0 & 9 & 100.0 & 0 & 0.0 & & 0 & 0.0 & 1 & 11.1 & 8 & 88.9 & \\
\hline & Maharashtra & 1 & 5.9 & 10 & 58.8 & 6 & 35.3 & & 0.0 & 0.0 & 17.0 & 100.0 & 0 & 0.0 & & 0 & 0.0 & 1 & 5.9 & 16 & 94.1 & \\
\hline & Odisha & 1 & 16.7 & 3 & 50.0 & 2 & 33.3 & & 1 & 16.7 & 5 & 83.3 & 0 & 0.0 & & 0 & 0.0 & 0 & 0.0 & 6 & 100.0 & \\
\hline
\end{tabular}




\begin{tabular}{|c|c|c|c|c|c|c|c|c|c|c|c|c|c|c|c|c|c|c|c|}
\hline & Rajasthan & 0 & 0.0 & 2 & 50.0 & 2 & 50.0 & 0 & 0.0 & 4 & 100.0 & 0 & 0.0 & 0 & 0.0 & 0 & 0.0 & 4 & 100.0 \\
\hline & Tamil Nadu & 29 & 12.7 & 149 & 65.4 & 50 & 21.9 & 7 & 3.1 & 211 & 92.5 & 10 & 4.4 & 11 & 4.8 & 55 & 24.1 & 162 & 71.1 \\
\hline & Telangana & 0 & 0.0 & 4 & 66.7 & 2 & 33.3 & 0 & 0.0 & 6 & 100.0 & 0 & 0.0 & 0 & 0.0 & 1 & 16.7 & 5 & 83.3 \\
\hline & Uttar Pradesh & 0 & 0.0 & 3 & 60.0 & 2 & 40.0 & 1 & 20.0 & 4 & 80.0 & 0 & 0.0 & 1 & 20.0 & 0 & 0.0 & 4 & 80.0 \\
\hline & West Bengal & 1 & 7.1 & 9 & 64.3 & 4 & 28.6 & 0 & 0.0 & 13 & 92.9 & 1 & 7.1 & 0 & 0.0 & 0 & 0.0 & 14 & 100.0 \\
\hline Average $(\%)$ & & & 7.6 & & 67.6 & & 24.7 & & 2.1 & & 96.0 & & 2.0 & & 3.2 & & 14.9 & & 81.9 \\
\hline
\end{tabular}

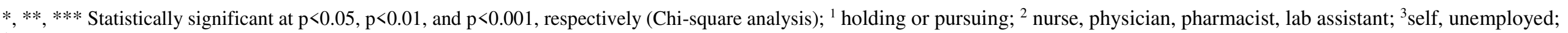
${ }^{4}$ Andaman and Nicobar Islands.

20

21

22

23

24

25

26

27

28

29

30

31

32

33 
Table 7: Correlation between scores of knowledge, attitude, and practice

\begin{tabular}{lll}
\hline Variable & Correlation Coefficient & p-value \\
\hline Knowledge-Attitude & 0.045 & 0.287 \\
Attitude-Practice & $0.164 * * *$ & $<0.001$ \\
Knowledge-Practice & $0.116 * *$ & 0.006 \\
\hline
\end{tabular}

36

$* *, * * *$ Correlation significant at 0.01 , and 0.001 level

37

38

39

40

41

42

43

44

45

46

47

48

49

50 
51 Figure 1. Distribution of KAP survey sample $(n=566)$ towards COVID-19 across various states of India (Created with paintmaps.com)

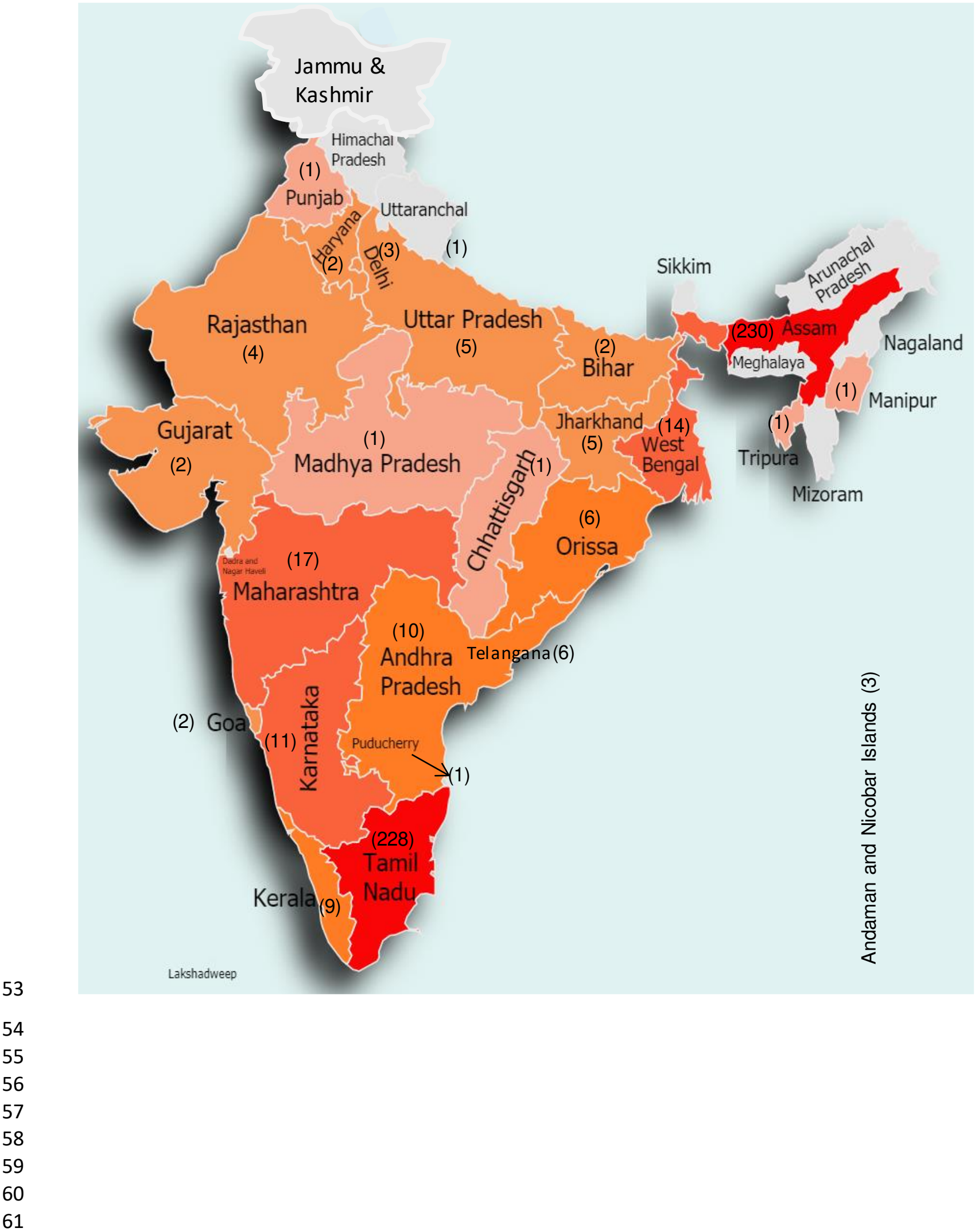


62 63

Figure 2. Risk of infection of COVID-19 among demographic variables of Indians $(n=566)$

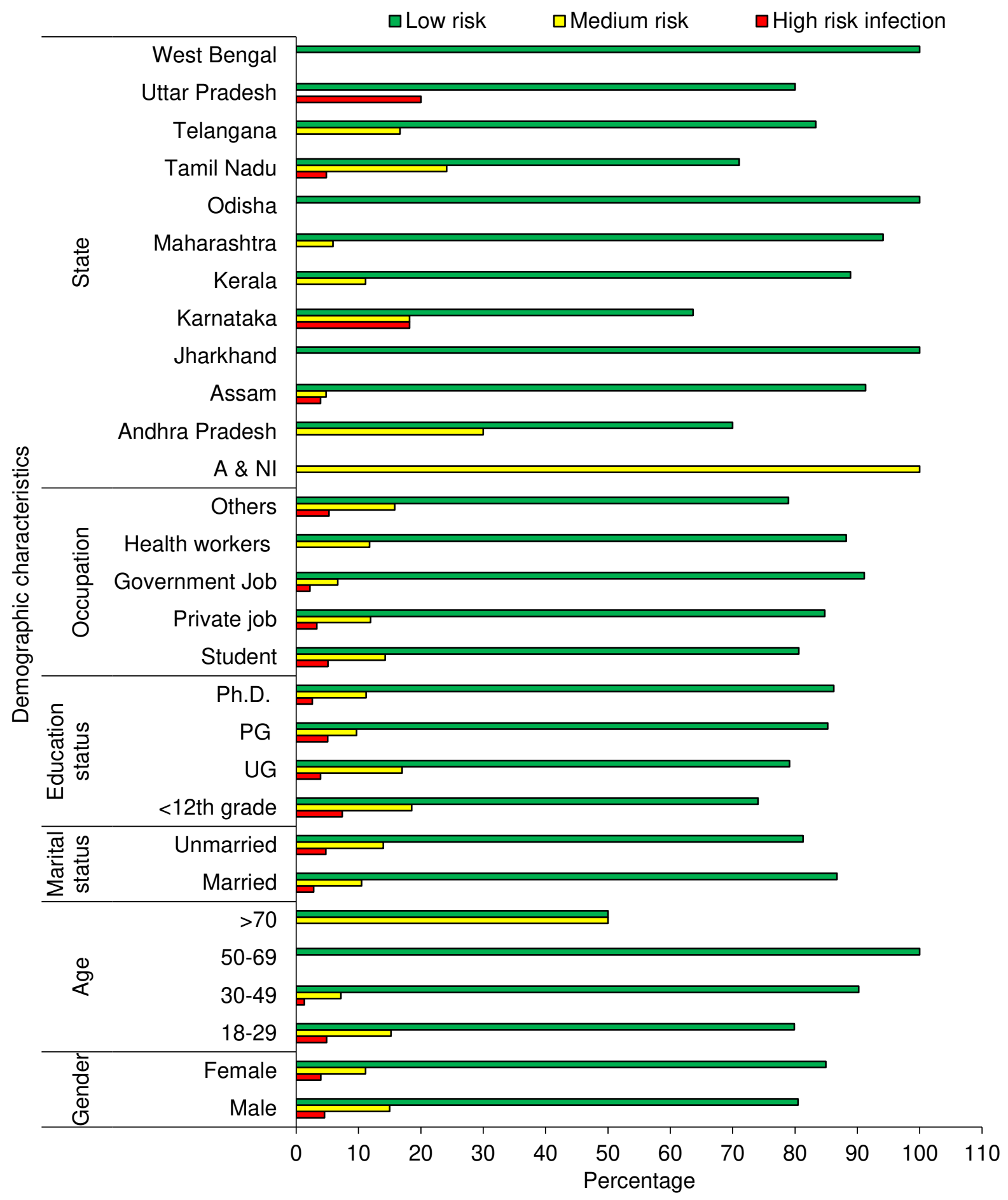

64

65

66 


\begin{tabular}{|c|c|c|c|}
\hline \multicolumn{2}{|c|}{ Knowledge Questions } & \multirow[t]{2}{*}{$\mathrm{n}$} & \multirow[t]{2}{*}{$\%$} \\
\hline K1 & Expansion of the COVID-19. & & \\
\hline & China originated Virus disease-2019 & 147 & 26.0 \\
\hline & Coronavirus Disorders-2019 & 21 & 3.7 \\
\hline & Coronavirus Disease-2019 & 387 & 68.4 \\
\hline & I don’t know & 11 & 1.9 \\
\hline \multirow[t]{6}{*}{$\mathrm{K} 2$} & Where was the first case of COVID-19 reported globally? & & \\
\hline & Shanghai & 9 & 1.6 \\
\hline & Wuhan & 541 & 95.6 \\
\hline & Tokyo & 4 & 0.7 \\
\hline & New Delhi & 8 & 1.4 \\
\hline & I don’t know & 4 & 0.7 \\
\hline \multirow[t]{6}{*}{ K3 } & In which state was the first case of COVID-19 reported in India? & & \\
\hline & Kerala & 450 & 79.5 \\
\hline & New Delhi & 39 & 6.9 \\
\hline & Maharashtra & 61 & 10.8 \\
\hline & Tamil Nadu & 5 & 0.9 \\
\hline & I don’t know & 11 & 1.9 \\
\hline \multirow[t]{6}{*}{ K4 } & Which virus causes COVID-19? & & \\
\hline & SARS & 80 & 14.1 \\
\hline & MERS & 9 & 1.6 \\
\hline & SARS-nCoV-1 & 87 & 15.4 \\
\hline & SARS-nCoV-2 & 345 & 61.0 \\
\hline & I don’t know & 45 & 8.0 \\
\hline \multirow[t]{5}{*}{ K5 } & How does COVID-19 spread mainly? & & \\
\hline & Air & 47 & 8.3 \\
\hline & Water & 0 & 0.0 \\
\hline & Infected person & 518 & 91.5 \\
\hline & Food & 1 & 0.2 \\
\hline \multirow[t]{4}{*}{ K6 } & Pet animals can spread COVID-19. & & \\
\hline & TRUE & 134 & 23.7 \\
\hline & FALSE & 371 & 65.5 \\
\hline & I don't know & 61 & 10.8 \\
\hline \multirow[t]{5}{*}{ K7 } & Select the three main symptoms of COVID- 19. & & \\
\hline & Dry cough, Fever, Shortness of breath & 503 & 88.9 \\
\hline & Wet cough, Fever, Shortness of breath & 40 & 7.1 \\
\hline & Dry cough, Shortness of breath, stomachache & 12 & 2.1 \\
\hline & Dry cough, Shortness of breath, vomiting & 11 & 1.9 \\
\hline \multirow[t]{4}{*}{ K8 } & For how many days are suspected people isolated and observed in quarantine? & & \\
\hline & 1 day & 0 & 0.0 \\
\hline & 4 days & 5 & 0.9 \\
\hline & 11 days & 1 & 0.2 \\
\hline
\end{tabular}




\begin{tabular}{|c|c|c|c|}
\hline & 14 days & 559 & 98.8 \\
\hline & I don’t know & 1 & 0.2 \\
\hline \multirow[t]{6}{*}{ K9 } & What is the Mortality rate (death rate) associated with COVID-19 worldwide? & & \\
\hline & $50 \%$ & 75 & 13.3 \\
\hline & $100 \%$ & 21 & 3.7 \\
\hline & $1 \%$ & 45 & 8.0 \\
\hline & $<10 \%$ & 377 & 66.6 \\
\hline & I don’t know & 48 & 8.5 \\
\hline \multirow[t]{6}{*}{ K10 } & What is the Mortality rate (death rate) associated with COVID-19 in India? & & \\
\hline & $50 \%$ & 29 & 5.1 \\
\hline & $100 \%$ & 6 & 1.1 \\
\hline & $<5 \%$ & 406 & 71.7 \\
\hline & $10 \%$ & 95 & 16.8 \\
\hline & I don't know & 30 & 5.3 \\
\hline \multirow[t]{6}{*}{ K11 } & $\begin{array}{l}\text { What is the recommended minimal social distancing norms (in feet) to prevent } \\
\text { COVID-19's spread? }\end{array}$ & & \\
\hline & 10 feet & 49 & 8.7 \\
\hline & 6 feet & 352 & 62.2 \\
\hline & 2 feet & 105 & 18.6 \\
\hline & 1 foot & 54 & 9.5 \\
\hline & I don’t know & 6 & 1.1 \\
\hline \multirow[t]{6}{*}{ K12 } & $\begin{array}{l}\text { How many seconds are suggested to clean your hands with soap to prevent COVID- } \\
\text { 19's spread? }\end{array}$ & & \\
\hline & 20 second & 485 & 85.7 \\
\hline & 5 seconds & 1 & 0.2 \\
\hline & 10 seconds & 20 & 3.5 \\
\hline & 60 seconds & 53 & 9.4 \\
\hline & I don’t know & 7 & 1.2 \\
\hline \multirow[t]{6}{*}{ K13 } & Which is the best preventive measure for COVID-19? & & \\
\hline & Wearing Nose mask & 23 & 4.1 \\
\hline & Washing hands & 30 & 5.3 \\
\hline & Stay at home & 305 & 53.9 \\
\hline & Social distancing & 206 & 36.4 \\
\hline & I don’t know & 2 & 0.4 \\
\hline \multirow[t]{6}{*}{ K14 } & If you have only one new nose mask, whom would you give the mask to wear? & & \\
\hline & A doctor who treats COVID patient & 46 & 8.1 \\
\hline & A nurse who helps the COVID patient & 21 & 3.7 \\
\hline & Your self & 139 & 24.6 \\
\hline & To the COVID patient & 348 & 61.5 \\
\hline & None of them & 12 & 2.1 \\
\hline \multirow[t]{4}{*}{ K15 } & Effective treatment is available for COVID- 19. & & \\
\hline & TRUE & 131 & 23.1 \\
\hline & FALSE & 402 & 71.0 \\
\hline & I don't know & 33 & 5.8 \\
\hline
\end{tabular}


K16 We cannot prevent COVID-19's spreading.

TRUE

$114 \quad 20.1$

FALSE

$437 \quad 77.2$

I don't know

$15 \quad 2.7$

K17 Vaccines are not available for COVID-19 at the moment.

TRUE

$517 \quad 91.3$

FALSE

$34 \quad 6.0$

I don't know

$\begin{array}{ll}15 & 2.7\end{array}$

K18 What is the genetic material of COVID-19 virus?

RNA

$427 \quad 75.4$

DNA

$59 \quad 10.4$

XNA

$\begin{array}{ll}15 & 2.7\end{array}$

I don't know

65

The option, highlighted in bold is the correct and appropriate answer for the respective question

68

69

70

71

72

73

74

75

76

77

78

79

80

81

82

83

84

85

86

87 


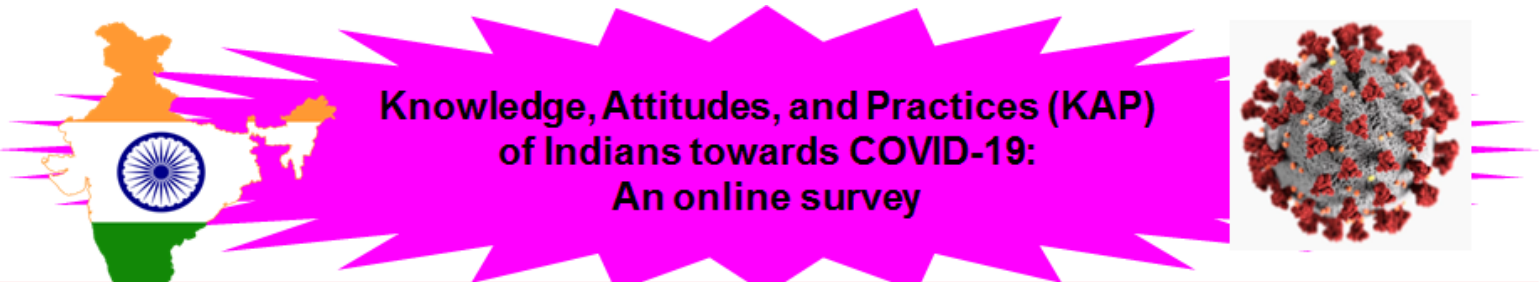

Introduction

COVID-19 has ushered in a catastrophe of an unprecedented scale across latitude and longitudes. As of today (18 May, 2020), against 4.8 million confirmed cases and a death toll of 0.3 million worldwide (the number being an upward trend daily). India has documented 96000 confirmed cases and 3000 deaths. Various measure has been adopted globally to control and contain the disease. In this regard, besides declaration of a lockdown and ensuring timely execution of the viral detection test, India is beavering away to combat the debacle through various suggestive measure. Some of the embrace maintenance of social distancing, wearing of nose masks, frequent washing of hands and avoidance of crowded places to stop community spreading. However, People's adherence to such control measures is affected by their KAP towards COVID-19. Therefore, the objective of this online survey is to investigate Indians' KAP towards the disease.

\section{Participants}

$\checkmark$ Participants should be Indian nationalities.

$\checkmark$ E-mail ID is must and E-certificate will be provided for the participation.

$\checkmark$ Reading and understanding of English is a must.

$\checkmark$ Age must be 15 and above.

$\checkmark$ Need internet connection

$\checkmark \quad$ Need to give some Socio-demographic data (age, gender, religion, job, educational status, marital status, and province).

$\checkmark \quad$ There are 40 questions (multiple choice, true and false, and Likert scale) related to KAP of COVID-19 and will take $15 \mathrm{~min}$.

Voluntary nature of participants

* Participants should answer a YES or NO question to confirm their willingness to participate voluntarily.

Declarations of anonymity and confidentiality

- Some data will be obtained from you regarding COVID-19 KAP. Your answers will be used for educational purposes only.

Note: Please answer all the questions. Your answers are very importan and that will facilitate the outbreak management of COVID-19.

\section{Link and QR code}

https://docs.google.com/form s/d/e/1FAlpQLSe9Ycww5fxPjO iTczCcT1wEmRyNcsAvMXQ6Bv f3fCGZdEkhtQ/viewform

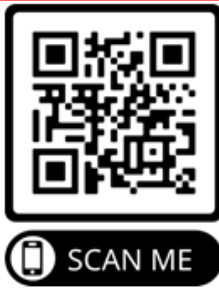

Thank you for your valuable time and participation Invigilators

Dr. A. Suresh, Assistant Professor, Phone:0902643433, suresh.suresh@aastu.edu.et

Dr. Rocktotpal Konwarh, Assistant Professor, Phone:0902642289, rocktotpal.konwarh@aastu.edu.et

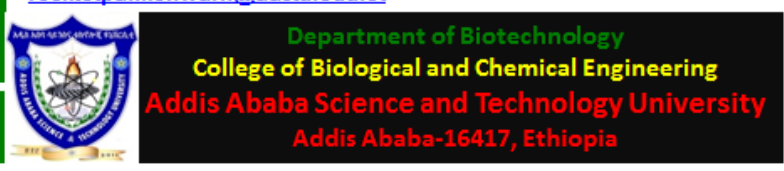




\section{Figures}

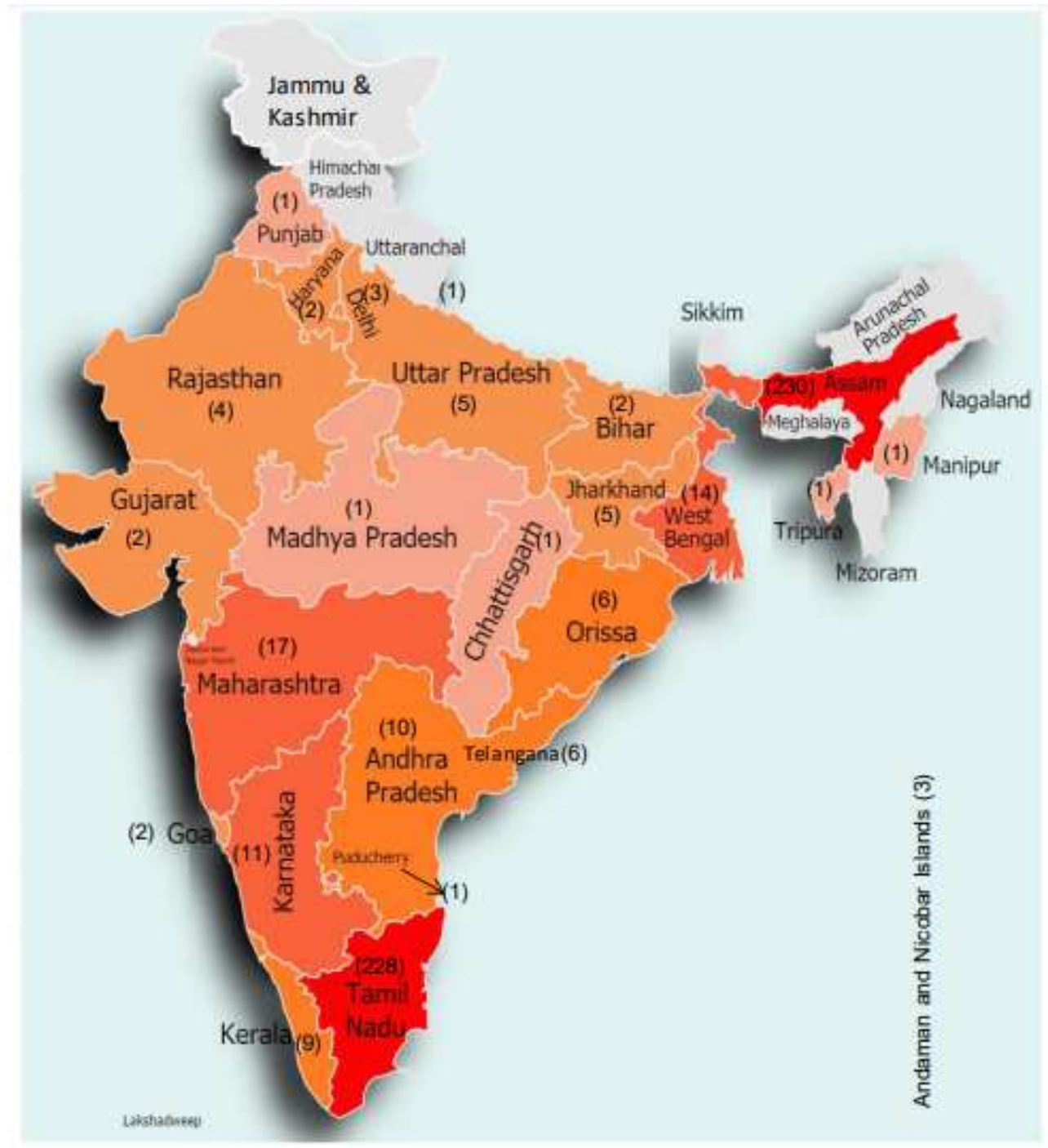

\section{Figure 1}

Distribution of KAP survey sample $(n=566)$ towards COVID-19 across various states of India (Created with paintmaps.com) 


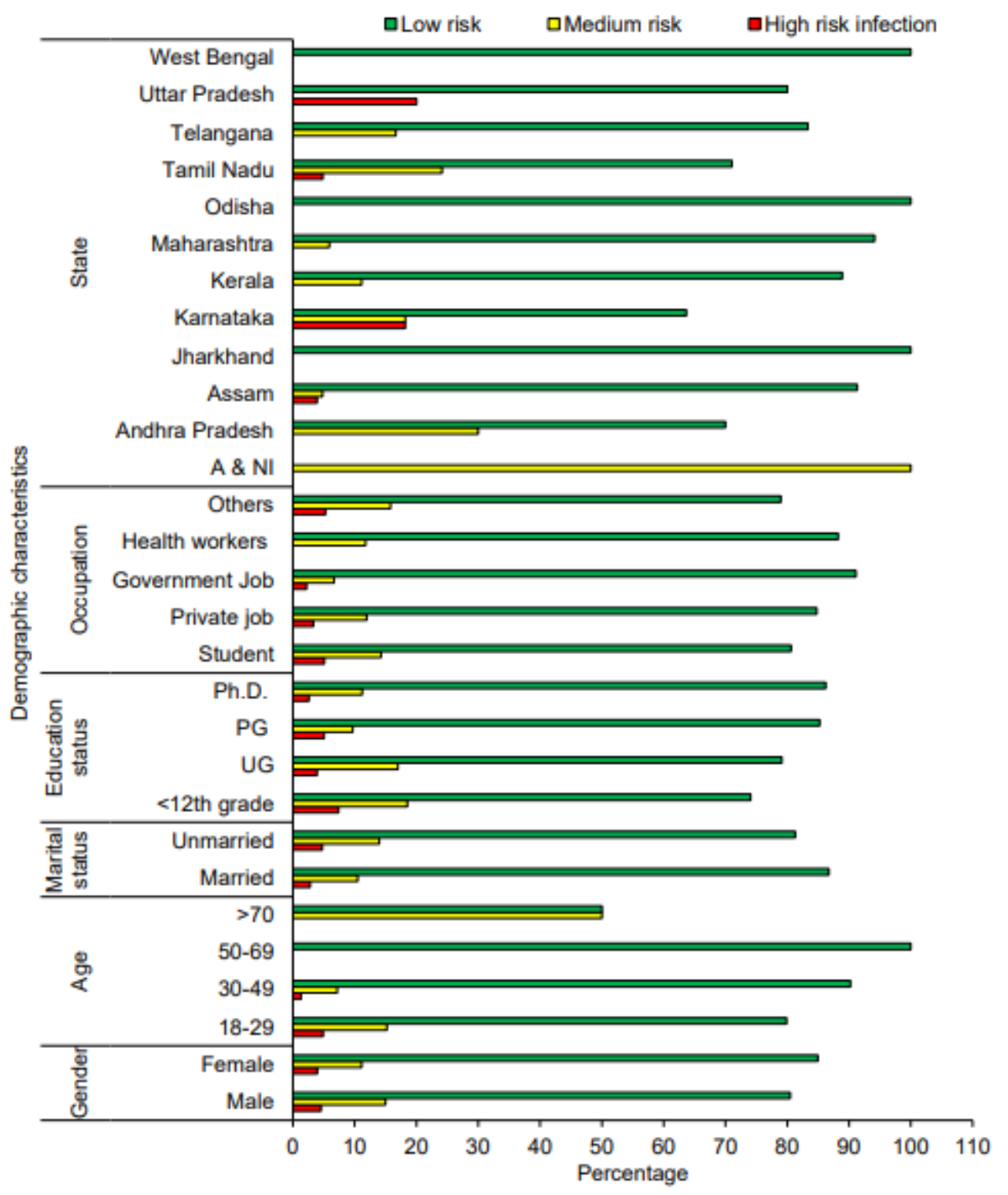

Figure 2

Risk of infection of COVID-19 among demographic variables of Indians $(n=566)$ 